\title{
Towards hydrogen and halogen bonded frameworks based on 3,5-bis(triazolyl)pyridinium motifs
}

\author{
Émer M. Foyle, Hui Min Tay, Nicholas G. White* \\ Research School of Chemistry, The Australian National University, Canberra, ACT, Australia \\ Email: nicholas.white@anu.edu.au Web:www.nwhitegroup.com
}

\begin{abstract}
We attempted to use hydrogen, iodo and seleno 3,5-bis(triazolyl)pyridinium (btp) motifs to form 3D supramolecular frameworks assembled by hydrogen, halogen or chalcogen bonding to anions. Initially, we prepared flexible ditopic and tetratopic receptors where the pyridinium nitrogen atom was functionalized with a benzylic group but were unable to crystallise extended frameworks. We subsequently developed the use of Zincke methodology to prepare rigid ditopic and tetratopic hydrogen and halogen bonding tectons, and were able to crystallize the sulfate derivative of a tetratopic receptor, although unfortunately this did not have the desired open framework. Several crystal structures were obtained with the receptors and monovalent anions, including one containing an unusually short iodotriazole- $\mathrm{Cl}^{-}$halogen bond. Generally, the btp triazole groups show a tendency to rotate away from the desired conformation and it appears that this may contribute to difficulties in obtaining 3D frameworks even when the receptors have a rigid core.
\end{abstract}

\section{Introduction}

Three dimensional frameworks assembled by hydrogen bonding (sometimes referred to as hydrogen bonded organic frameworks, HOFs) have received significant research interest, particularly in the last decade or so. ${ }^{1,2}$ This is largely because the relatively weak nature of hydrogen bonds often gives rise to highly crystalline materials that can be prepared in milder conditions than those used to prepare coordination polymers/metal organic frameworks (CPs/MOFs) ( $^{3,4}$ or covalent organic frameworks (COFs). ${ }^{5,6}$ A number of different hydrogen bonding motifs have been used to construct these frameworks, using either the self-recognition of a neutral component ${ }^{7-14}$ or the interaction between two charged tectons. ${ }^{15-23}$ While many frameworks have been reported, these have typically used a relatively limited set of hydrogen bonding motifs. ${ }^{1,2}$

Halogen bonding and chalcogen bonding are two other types of supramolecular interactions that can be relatively strong and are distinguished from hydrogen bonds by their more stringent linearity. ${ }^{24-28}$ Potentially this linearity would make them ideal motifs for the formation of supramolecular frameworks as it should lead to predictable structures. Despite this possible advantage, relatively few 3D frameworks assembled by halogen ${ }^{29-38}$ or chalcogen ${ }^{39-43}$ bonding have been reported. Indeed we are only aware of one halogen bonded framework ${ }^{37}$ and one chalcogen bonded ${ }^{42}$ framework that are sufficiently stable to allow for solvent removal and subsequent gas sorption studies.

Given the relative lack of diversity in building blocks used to prepare hydrogen bonded frameworks, and the small number of halogen and chalcogen bonded materials known, we decided to investigate new tectons for the synthesis of su

pramolecular frameworks. To this end, we were attracted to the 3,5-bis(triazolyl)pyridinium (btp) motif, which was first reported by Li and Li in 2011, ${ }^{44}$ and subsequently developed as an anion recognition motif by Beer. ${ }^{45}$ This motif contains a positive charge as well as potentially bidentate hydrogen bond donors, and variants containing halogen $^{46}$ and chalcogen bond ${ }^{47}$ donors have been reported. These have proven to be particularly potent anion receptors, ${ }^{48-51}$ as well as useful for anion binding catalysis. ${ }^{52}$

Of particular interest to us was a crystal structure reported by Beer, which showed two iodo-btp groups arranged around a sulfate anion (Figure 1). ${ }^{48}$ In this case, each iodo-btp motif belongs to a different [2]catenane molecule, but despite the conformational restrictions imposed by this, the btp molecules were able to arrange themselves around a sulfate anion. This gives a charge neutral assembly, ${ }^{53}$ and we wondered whether the btp motif could be used to deliberately construct supramolecular frameworks using sulfate or other appropriate $2^{-}$anions to link the building blocks. Herein, we describe our attempts to prepare 3D frameworks using the btp motif and various anionic species.<smiles>[X]c1c(-c2cc(-c3nnn([R])c3[X])c[n+]([R])c2)nnn1[R]</smiles>
$\mathrm{X}=\mathrm{H}, \mathrm{I}$
Se-Me, Te-Me

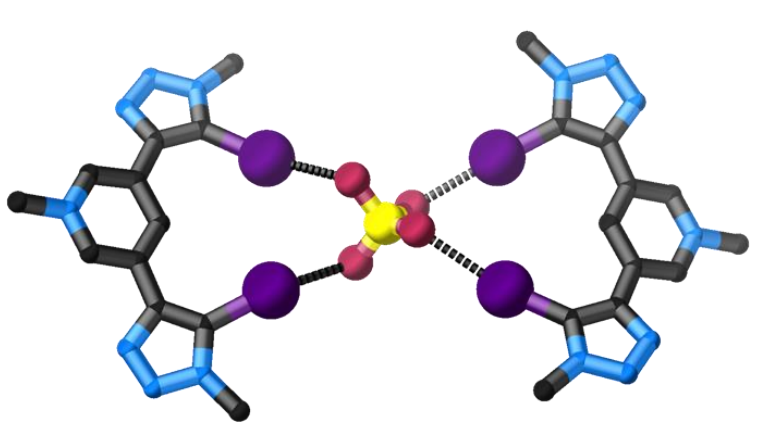

Figure 1 General structure of btp motif, and partial crystal structure showing two iodobtp receptors arranged around a sulfate anion reported by Beer ${ }^{48}$ (CSD:1033648). 


\section{Results and discussion}

Synthesis of neutral hydrogen and halogen bonding motifs The key feature in all the structures in this work is the bis(triazolyl)pyridinium (btp) motif with either hydrogen or iodine groups attached to the triazoles rings, i.e. either prototriazole or iodotriazole groups. We also investigated the synthesis of a chalcogen bonding motif containing $\mathrm{R}$ Se groups at the 5-position of the triazole ring. While we were able to prepare some selenium functionalised btp derivatives, we were unable to obtain any crystals from these and so the syntheses of these are described in the Supporting Information.

To prepare the triazole and iodotriazole btp derivatives, commercially available 3,5-dibromopyridine was converted to the known molecule 3,5-diethynylpyridine in high yield through a Sonogashira coupling with TMSacetylene followed by deprotection ${ }^{54}$ (an optimised procedure is given in the Supporting Information). One-pot syntheses were then used to convert either hexyl bromide or benzyl bromide to the corresponding azide and then react these with diethynylpyridine under copper-catalysed azide alkyne coupling conditions to give known hexyl substituted btp $1^{\mathrm{H}_{\text {hex }}}{ }^{45}$ and the new benzyl substituted btp $1^{\mathrm{H}_{\mathrm{Bn}}}$ (Figure 2). We formed the known benzyl substituted iodotriazole btp $1^{\prime} \mathrm{Bn} 52$ from diethynylpyridine, sodium iodide and benzyl azide using copper(II) triflate as the catalyst, ${ }^{52}$ with an alternative procedure using copper(II) perchlorate $^{48}$ not giving complete conversion to the product in our hands.

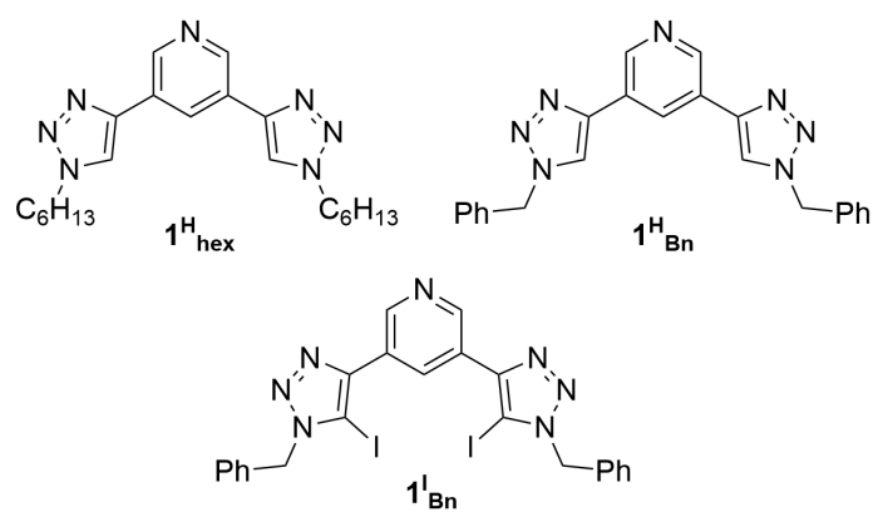

Figure 2 Btp precursors used in this work $\left(\mathbf{1}_{\mathrm{Bn}}\right.$ is a new compound, $\mathbf{1}_{\mathrm{hex}}{ }^{45}$ and $1_{\mathrm{Bn}}{ }^{52}$ have been reported previously).

\section{Synthesis of flexible ditopic and tetratopic btp receptors}

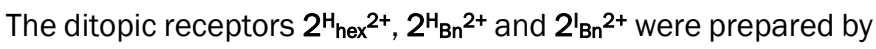
heating the appropriate neutral btp derivative and bis(bromomethyl)benzene to reflux in acetonitrile (Scheme 1). The bromide salts of these receptors precipitated from the reaction mixture and could be isolated in good yields (64-93\%) and high purities by simple filtration. The hydrogen bonding receptors were exchanged to their $\mathrm{PF}_{6}{ }^{-}$salts $\left[i . e .{ }^{2}{ }_{\text {hex }}\left(\mathrm{PF}_{6}\right)_{2}\right.$ and $2 \mathrm{H}_{\mathrm{Bn}} \cdot\left(\mathrm{PF}_{6}\right)_{2}$ ] by precipitation from $\mathrm{DMF} /$ methanol using $\mathrm{NH}_{4} \mathrm{PF}_{6}$. When we used this procedure to prepare $2^{1}{ }_{\mathrm{Bn}} \cdot\left(\mathrm{PF}_{6}\right)_{2}$, we obtained a crystal structure of a compound that contained some bromide anions suggesting that complete anion exchange was not observed (see Supporting Information). We suggest that this may be due to the well known high affinity of iodo-substituted btp groups for halide anions. ${ }^{46,48}$ Instead, we were able to prepare $2^{\prime}{ }_{B n} \cdot\left(B F_{4}\right)_{2}$ using silver(I) tetrafluoroborate.

The tetratopic receptors were prepared by heating the neutral btp derivatives $1^{\mathrm{H}_{\mathrm{Bn}}}$ and $1_{\mathrm{Bn}}^{\mathrm{B}}$ and tetra bromomethyl compound 3 to reflux in acetonitrile (Scheme 1 ). The receptors $4^{\mathrm{H}} \cdot \mathrm{Br}_{4}$ and ${ }^{4} \cdot \mathrm{Br}_{4}$ precipitated from the reaction mixtures and were isolated in 66 and $64 \%$ yields by simple filtration. Anion

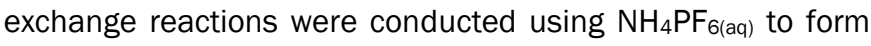
${ }^{\mathrm{H}}{ }^{\mathrm{H}}\left(\mathrm{PF}_{6}\right)_{4}$ and $\mathrm{AgBF}_{4}$ to form ${ }^{\mathrm{I}}{ }_{\mathrm{Bn}} \cdot\left(\mathrm{BF}_{4}\right)_{4}$.

\section{Attempts to form 1D and 3D frameworks from flexible receptors}

We attempted to crystallise the ditopic and tetratopic receptors with anions suitable to link these into either 1D or 3D networks through hydrogen/halogen bonding. Specifically, we looked at sulfate, terephthalate and the tetrahedral tetracarboxylate 54- $^{4}$ (Figure 3). Despite trialling numerous crystallisation solvents we were unable to obtain any crystals suitable for X-ray crystallography with either TP2- or 54-. 
<smiles></smiles>

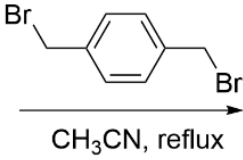<smiles>[X]c1c(-c2cc(-c3nnn([R])c3[X])c[n+](Cc3ccc(C[n+]4cc(-c5nnn([R])c5[X])cc(-c5nnn([R])c5[X])c4)cc3)c2)nnn1[R]</smiles><smiles>BrCc1ccc([Si](c2ccc(CBr)cc2)(c2ccc(CBr)cc2)c2ccc(CBr)cc2)cc1</smiles>

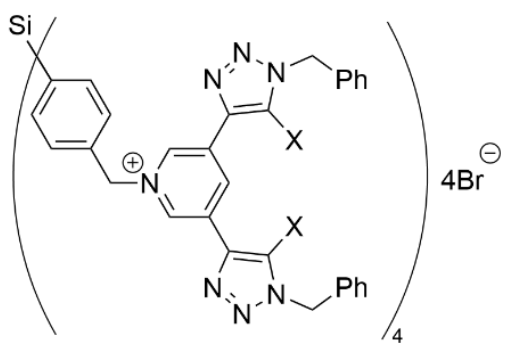

$4 \cdot \mathrm{Br}_{4}$
$\mathrm{R}=$ hexyl, $\mathrm{X}=\mathrm{H}, \mathbf{2}^{\mathrm{H}}{ }_{\text {hex }} \cdot \mathrm{Br}_{2}, 64 \%$

$\mathrm{R}=$ benzyl, $\mathrm{X}=\mathrm{H}, \mathbf{2}^{\mathrm{H}} \mathrm{Bn}^{\prime} \cdot \mathrm{Br}_{2}, 93 \%$

$\mathrm{R}=$ benzyl, $\mathrm{X}=\mathrm{I}, 2^{\mathrm{l}} \mathrm{Bn}^{\mathrm{B}} \cdot \mathrm{Br}_{2}, 80 \%$
$\mathrm{X}=\mathrm{H}, 4^{\mathrm{H}} \cdot \mathrm{Br}_{4}, 66 \%$

$\mathrm{X}=\mathrm{I}, \mathbf{4}^{\mathrm{l}} \cdot \mathrm{Br}_{4}, 64 \%$

Scheme 1 Synthesis of flexible ditopic receptors $2 \mathrm{H}_{\text {hex }} \cdot \mathrm{Br}_{2}, 2^{\mathrm{H}} \mathrm{H}_{\mathrm{Bn}} \cdot \mathrm{Br}_{2}$ and ${ }^{2}{ }_{\mathrm{Bn}} \cdot \mathrm{Br}_{2}$, and flexible tetratopic receptors $4{ }^{\mathrm{H}} \cdot \mathrm{Br}_{4}$ and $4{ }^{1} \cdot \mathrm{Br}_{4}$. All of these receptors were also anion exchanged to give the corresponding $\mathrm{BF}_{4}^{-}$or $\mathrm{PF}_{6}{ }^{-}$salts.<smiles>O=S(=O)([O-])[O-]</smiles><smiles>O=C([O-])c1ccc(C(=O)[O-])cc1</smiles>

$\mathrm{TP}^{2}$<smiles>O=C([O-])c1ccc(C(c2ccc([18F])cc2)(c2ccc(C(=O)O)cc2)c2ccc(C(=O)O)cc2)cc1</smiles>

Figure 32 2- and 4- anions used in crystallisation studies.

We were able to obtain crystals by vapour diffusion techniques when we used mixtures of either $2^{\mathrm{H}_{\text {hex }}}\left(\mathrm{PF}_{6}\right)_{2}$ or $2^{1}{ }_{\mathrm{Bn}} \cdot\left(\mathrm{BF}_{4}\right)_{2}$ and $\mathrm{TBA}_{2} \cdot \mathrm{SO}_{4}(\mathrm{TBA}=$ tetrabutylammonium). Unfortunately in both cases, $\mathrm{X}$-ray crystallography revealed that the crystals were of the $\mathrm{HSO}_{4}{ }^{-}$salt of the receptor (Figure 4). Testing the $\mathrm{pH}$ of the " $\mathrm{TBA}_{2} \cdot \mathrm{SO}_{4}$ " used, revealed that it was significantly acidic, suggesting the presence of significant amounts $\mathrm{HSO}_{4}^{-}\left(\mathrm{pK}_{\mathrm{a}}\right.$ of $\mathrm{HSO}_{4}{ }^{-} \sim 2{ }^{55}$ ). Attempts to crystallise these receptors with a fresh batch of $\mathrm{TBA}_{2} \cdot \mathrm{SO}_{4}$, which was not acidic, were unsuccessful.

In both the structures of $2^{\mathrm{H}_{\text {hex }}}\left(\mathrm{HSO}_{4}\right)_{2}$ and $2^{\mathrm{I}} \mathrm{Bn}^{-}\left(\mathrm{HSO}_{4}\right)_{2}$, the $\mathrm{HSO}_{4}{ }^{-}$anions are located in the btp pockets, although it is notable that the actual mode of binding to the anion is quite different in each structure. In the case of $2^{\mathrm{H}_{\text {hex }}}\left(\mathrm{HSO}_{4}\right)_{2}$, one crystallographically independent triazole $\mathrm{C}-\mathrm{H}$ group points into the cleft, while the other points out; this therefore means that a triazole nitrogen atom points towards the $\mathrm{HSO}_{4}{ }^{-}$anion, and forms a short hydrogen bond with the hydrogen atom of the $\mathrm{HSO}_{4}{ }^{-}$anion $(\mathrm{H}-\mathrm{N}=1.90 \AA, 66 \%$ of the sum of the van der Waals radii of these atoms, ${ }^{56} \sum_{\mathrm{vdw}}$ ). Interestingly the triazole hydrogen atom that does point into the cleft does not form a significant hydrogen bond to the anion ( $>$ than the sum of the van der Waals radii) and instead there is a relatively long hydrogen bond from the interior pyridinium hydrogen atom to the $\mathrm{HSO}_{4}^{-}$anion $\left(\mathrm{H}-\mathrm{O}=2.50 \AA, 92 \% \Sigma_{\mathrm{vdw}}\right)$.

Conversely, the structure of $2^{1}{ }_{\mathrm{Bn}} \cdot\left(\mathrm{HSO}_{4}\right)_{2}$ has both crystallographically independent iodotriazole rings pointing into the binding cleft and forming short halogen bonds to the anion's oxygen atoms ( $1-0=2.826(9), 2.890(7) \AA$; 80, $\left.82 \Sigma_{\text {vaw }}\right)$. These interactions are relatively close to $180^{\circ}$, although not as linear as some halogen bonds (<C-I-O: 171.9(2) and $164.8(3)^{\circ}$ for the shorter and longer interaction, respectively). The anion's hydrogen atom then hydrogen bonds to a methanol solvent molecule, and the anion and solvent form a hydrogen bonded chain (Figure 4c). 


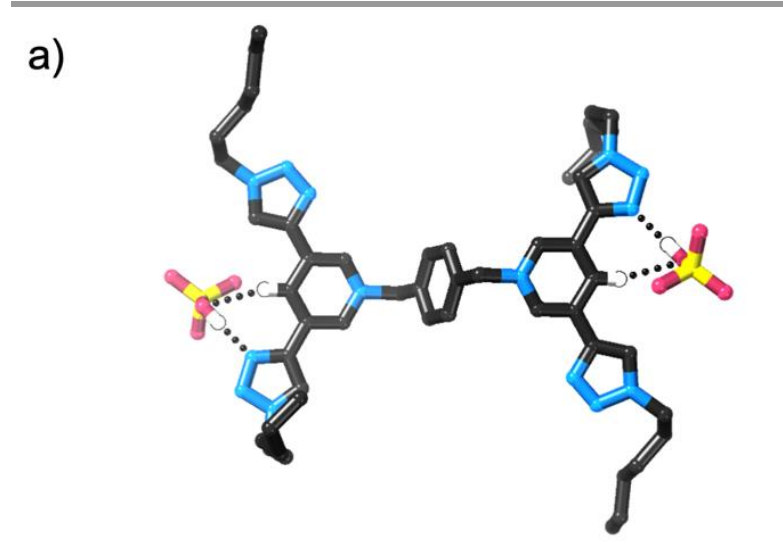

b)
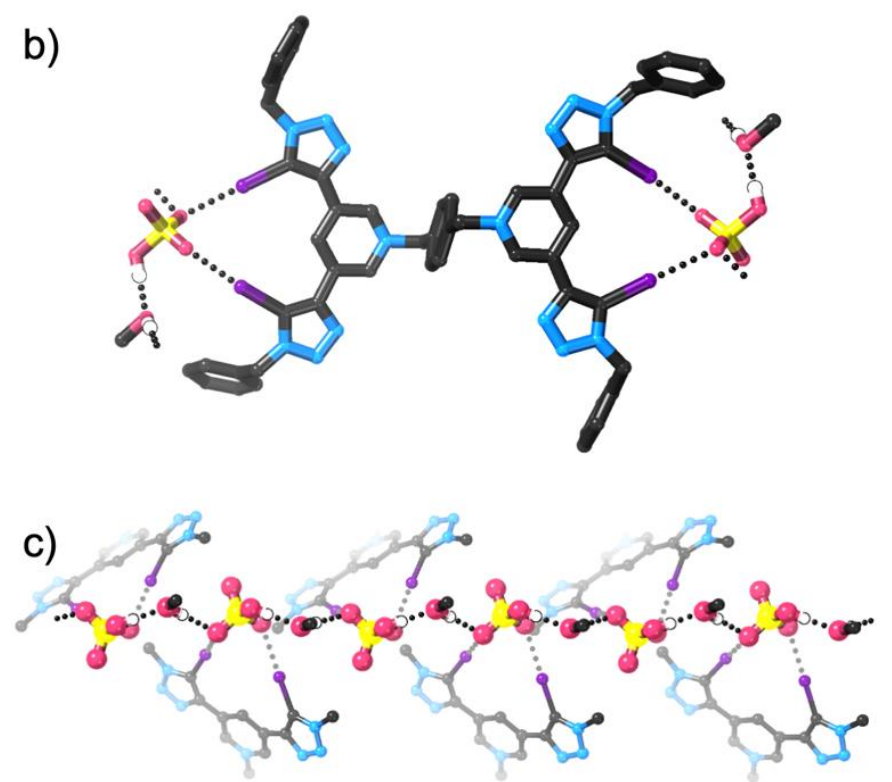

Figure 4 Structures of $\mathrm{HSO}_{4}$ - complexes of $2 \mathrm{H}_{\text {hex }}$ and $2^{\mathrm{I}} \mathrm{Bn}$ : a) structure of $2 \mathrm{H}_{\text {hex }}\left(\mathrm{HSO}_{4}\right)_{2}$, b) structure of $2^{1}{ }^{1} \cdot\left(\mathrm{HSO}_{4}\right)_{2}, \mathrm{C}$ ) structure of $\mathrm{HSO}_{4}{ }^{-}$methanol hydrogen bonded polymer in the structure of $2^{1}{ }_{\mathrm{Bn}}$. $\left(\mathrm{HSO}_{4}\right)_{2}$. Only hydrogen atoms involved in hydrogen bonding are shown, with hydrogen bonds shown as dotted lines. PLATON-SQUEEZE ${ }^{57}$ was used in the refinement of $2 \mathrm{H}_{\text {hex }}\left(\mathrm{HSO}_{4}\right)_{2}$.

We also obtained crystals when we crystallised $2^{\prime}{ }_{B n} \cdot\left(B F_{4}\right)_{2}$ in the presence of tetrabutylammonium terephthalate from a mixture of dichloromethane, acetonitrile and methanol. In this case, the crystals are of the chloride salt, $2^{\prime}{ }_{\mathrm{Bn}} \cdot \mathrm{Cl}_{2}$ (Figure 5). It is unclear where this chloride anion has come from, but we suggest it may result from breakdown of dichloromethane over the extended time period used to grow crystals. Given that strong halogen bond donors have been used as organocatalysts for halide abstraction,58-60 it is plausible that $2^{\prime}{ }_{B n}$ can cause the breakdown of small amounts of dichloromethane over long periods of time.

In the structure of $2^{1}{ }^{\prime} \cdot{ }^{n} \cdot C_{2}$, one crystallographically independent iodotriazole group points into the btp binding cleft, while the other points in the opposite direction. Each iodotriazole group forms a short halogen bond to a chloride anion $\left(\mathrm{l}-\mathrm{Cl}=2.987(1), 3.053(1) \AA ; 77,79 \% \Sigma_{\mathrm{vaw}}\right)$ and these interactions are close to linear $\left(<\mathrm{C}-1-\mathrm{Cl}^{-}: 172.6(1)\right.$ and $178.8(1)^{\circ}$ for the shorter and longer interaction, respectively). a)

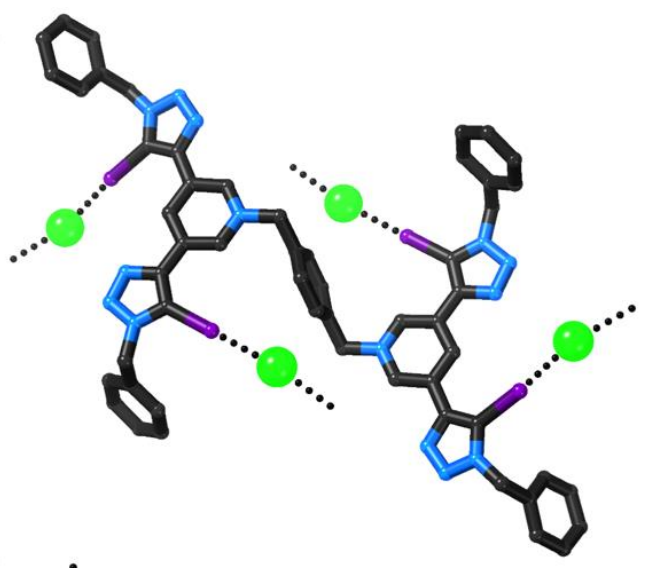

b)

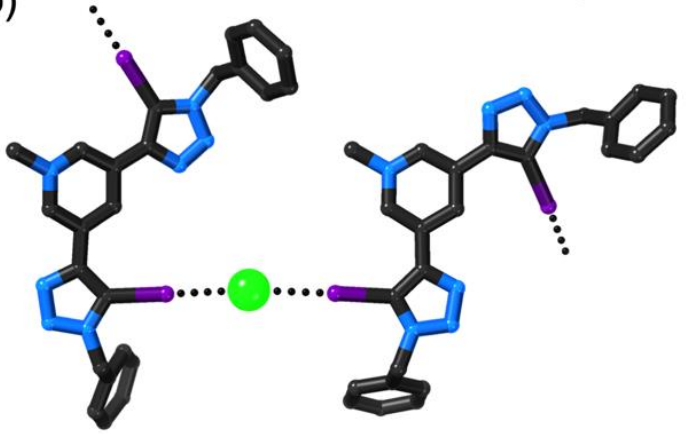

Figure 5 Two views of the structure of $2^{1}{ }_{\mathrm{Bn}} \cdot \mathrm{Cl}_{2}:$ a) view showing a complete receptor with all positions of the anion, b) view showing two partial receptors forming linear interactions with a single anion. Halogen bonds shown as dotted lines, hydrogen atoms omitted for clarity.

These $\mathrm{I}^{-\mathrm{Cl}^{-}}$contacts observed in the structure of $2^{1} \mathrm{Bn} \cdot \mathrm{Cl}$ seemed surprisingly short, and so we surveyed the Cambridge Structural Database ${ }^{61}$ (CSD) to compare these with related systems. Indeed, the $77 \% \Sigma_{\text {vaw }}$ interaction is shorter than any other iodotriazole-halide interaction in the database (Table 1). The $\mathrm{I}^{-} \mathrm{O}^{-}$interactions observed in the structure of $2^{\mathrm{I}} \mathrm{Bn}^{\cdot}\left(\mathrm{HSO}_{4}\right)_{2}$ are slightly shorter than the average iodotriazole-oxoanion contact observed in the database, although it is notable that the length of these interactions varies much more than those of iodotriazole-halides.

Table 1 Length (as $\% \Sigma_{\mathrm{vdw}}$ ) of halogen bonds in the CSD for iodotriazole groups and various anions.

\begin{tabular}{lcccc}
\hline & $\mathrm{Cl}^{-}$ & $\mathrm{Br}^{-}$ & $\mathrm{I}^{-}$ & Oxoanions \\
\hline Minimum & 78 & 82 & 82 & 73 \\
Maximum & 86 & 86 & 88 & 97 \\
Number & 16 & 4 & 9 & 10 \\
Mean & 81 & 83 & 85 & 84 \\
\hline
\end{tabular}

We attempted to use anions to link tetratopic receptors $4^{\mathrm{H} 4+}$ and $\mathbf{4}^{14+}$ into 3D frameworks but despite numerous attempts to crystallise these using sulfate, $\mathrm{TP}^{2-}$ or $\mathbf{5}^{\mathbf{4}}$, no crystals were obtained. We hypothesised that this may be due to the flexibility imparted by the methylene groups in the receptors leading to numerous possible conformations and making crystallisation difficult, and we note that the vast majority of known hydrogen bonded frameworks include highly rigid 
building blocks. To this end, we next sought to prepare more rigid receptors without these methylene groups.

\section{Synthesis of rigid ditopic and tetratopic btp receptors}

To increase the rigidity of the systems, we sought to prepare receptors with direct aryl-pyridinium bonds, i.e. to remove the methylene groups present in $\mathbf{2}^{2+}$ and $\mathbf{4}^{\mathbf{4 +}}$. This can be achieved using Zincke methodology, where the substituted pyridine group is reacted with chlorodinitrobenzene to form a "Zincke salt," i.e. a substituted 2,4-dnitrophenylpyridinium compound, which then reacts with a primary aniline to give the phenylpyridinium bond. While there are well-established methodologies for forming Zincke salts containing simple substituents, there are few reports of more complex salts forming. Additionally the reaction is known to struggle when there are electron-withdrawing substituents on the pyridine ring. ${ }^{62}$ Perhaps unsurprisingly, it was therefore quite difficult to form Zincke salts from $1^{H_{B n}}$ or $1^{\prime}{ }_{B n}-$ however, after considerable optimisation, we were able to form $6^{\mathrm{H}} \cdot \mathrm{Cl}$ in moderate yields (Scheme 2). This required heating a large excess of chlorodinitrobenzene and $1^{\mathrm{H}} \mathrm{Bn}$ in ethanol at $120{ }^{\circ} \mathrm{C}$ in a sealed vial for ten days, and even under these conditions, yields were modest (35\%). The modest yield is due to both incomplete reaction, and difficulties in purification - as $6^{\mathrm{H}} \cdot \mathrm{Cl}$ decomposes on silica gel. Attempts to scale up the reaction (using $>0.5 \mathrm{~g}$ of $1^{\mathrm{H}_{\mathrm{Bn}}}$ ) were difficult as the product could no longer be separated by recrystallization. The synthesis of $6^{\mathrm{l}} \cdot \mathrm{Cl}$ was even more challenging, as $1^{\prime} \mathrm{Bn}$ decomposed at $120^{\circ} \mathrm{C}$ and had poor solubility in ethanol. After optimisation, it was possible to achieve a $7 \%$ yield of $6 \mathbf{l}^{\mathrm{Cl}} \mathrm{Cl}$ by reacting $1^{1} \mathrm{Bn}$ with ten equivalents of dichloronitrobenzene in 1:1 ethanol:DMF for ten days at $95{ }^{\circ} \mathrm{C}$. This reaction does not go to completion and large amounts of unreacted starting material were observed meaning that the product required extensive and laborious purification by precipitation and washings (6. $\mathrm{Cl}$ decomposes on silica gel).<smiles>CCO[R6](=O)O[Na]</smiles><smiles>[X]c1c(-c2cc[n+](-c3cc(-c4nnn(Cc5ccccc5)c4[X])cn3-c3cc(-c4nnn(Cc5ccccc5)c4[X])cc(-c4nnn(Cc5ccccc5)c4[X])c3)cc2)nnn1Cc1ccccc1</smiles><smiles>[X]c1c(-c2cc(-c3nnn(Cc4ccccc4)c3[X])c[n+](-c3ccc([N+](=O)[O-])cc3[N+](=O)[O-])c2)nnn1Cc1ccccc1</smiles><smiles>Nc1ccc(C(c2ccc(N)cc2)(c2ccc(N)cc2)c2ccc(C(=O)O[Al])cc2)cc1</smiles>

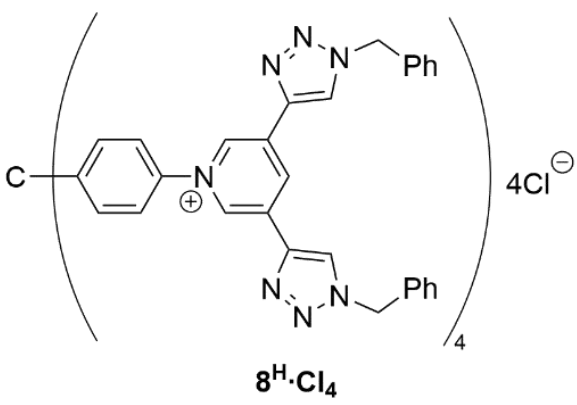

Scheme 2 Synthesis of Zincke salts $6{ }^{H \cdot} \cdot \mathbf{C l}$ and $6{ }^{\prime} \cdot \mathbf{C l}$, and rigid receptors $7{ }^{H} \cdot \mathrm{Cl}_{2}, 7 \mathrm{I}^{-} \mathrm{Cl}_{2}$ and $8^{\mathrm{H}} \cdot \mathrm{Cl}_{4}$. The ditopic and tetratopic receptors were also anion exchanged to give the corresponding $\mathrm{BF}_{4}^{-}$or $\mathrm{PF}_{6}-$ salts. 
With routes to the two Zincke salts in-hand, we next prepared the rigid ditopic receptors $7{ }^{\mathrm{H}} \cdot \mathrm{Cl}_{2}$ and $7 \mathrm{l} \cdot \mathrm{Cl}_{2}$ by simply heating an excess of the salt with 1,4-diaminobenzene in 1:1 ethanol:water (Scheme 2). This gave the rigid receptors in 80 and $39 \%$ yields, respectively, after sonicating in acetonitrile to remove excess Zincke salt. Anion exchange using $\mathrm{NH}_{4} \mathrm{PF}_{6(\mathrm{aq})}$ and $\mathrm{AgBF}_{4}$ gave $7^{\mathrm{H}} \cdot\left(\mathrm{PF}_{6}\right)_{2}$ and $7^{\mathrm{l}} \cdot\left(\mathrm{BF}_{4}\right)_{2}$, respectively.

Due to the low yielding reaction to form $6 \mathbf{l} \cdot \mathbf{C l}$, we only isolated small amounts of this compound and so were unable to pursue the synthesis of $\mathbf{8}^{14+}$. We prepared the rigid tetratopic receptor $8^{\mathrm{H} 4+}$ by reacting an excess of $6^{\mathrm{H}} \cdot \mathrm{Cl}$ with tetraamine 9 (Scheme 2). The reaction was sluggish, and even after heating for seven days, the yield for this compound was modest (32\%). Nevertheless, it was possible to isolate clean $8^{\mathrm{H}} \cdot \mathrm{Cl}_{4}$ after purification by sonicating in acetonitrile and then in acetone. Anion exchange using $\mathrm{NH}_{4} \mathrm{PF}_{6(\text { aq })}$ gave $8^{\mathrm{H}_{-}}\left(\mathrm{PF}_{6}\right)_{4}$.

\section{Attempts to form 1D and 3D frameworks from rigid receptors}

We attempted to crystallise $7^{\mathrm{H} 2+}$ and $7^{12+}$ with sulfate, TP2- or $5^{4-}$ in order to form hydrogen bonded chains, but were not able to obtain crystals. We were able to crystallise $7 \mathrm{H}^{-} \mathrm{Cl}_{2}$ by vapour diffusion of diethyl ether into a methanol solution of the compound. As shown in Figure 6, the two chloride anions sit in the btp pockets with all four triazoles $\mathrm{C}-\mathrm{H}$ groups pointing "outwards" to hydrogen bond to the anions. There are relatively short hydrogen bonds between the anions and triazole groups $\left(\mathrm{H}^{-\mathrm{Cl}^{-}}\right.$: $2.51-2.69 \AA$, 83-89\% $\left.\Sigma_{\mathrm{vdw}}\right)$ and between the anions and the internal pyridinium proton $\left(\mathrm{H}^{-} \mathrm{Cl}^{-}: 2.56,2.60 \AA .85\right.$, $\left.86 \% \Sigma_{v d w}\right)$. The coordination sphere of each chloride anion is completed by two more hydrogen bonds: in one case from the methanol solvent and from a $\mathrm{C}-\mathrm{H}$ group from the phenylene ring of a neighbouring receptor, in the other case by two $\mathrm{C}-\mathrm{H}$ hydrogen bonds from phenylene rings. The hydrogen bond with methanol is quite short $\left(\mathrm{H}^{-} \mathrm{Cl}^{-}: 2.33 \AA\right.$, $\left.77 \% \Sigma_{\mathrm{vdw}}\right)$, while those with phenylene $\mathrm{C}-\mathrm{H}$ groups are longer $\left(\mathrm{H}^{-} \mathrm{Cl}-:\right.$ : $2.60-2.70 \AA$, 86-89\% $\Sigma_{\mathrm{vdw}}$ ).

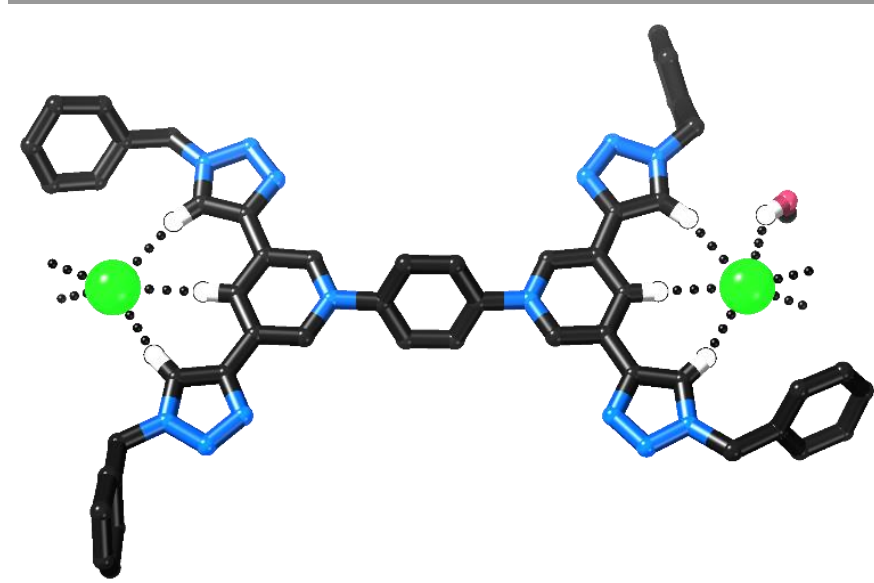

Figure 6 Structure of $7 \mathrm{H}^{-} \mathrm{Cl}_{2}$ : only hydrogen atoms involved in hydrogen bonding are shown, hydrogen bonds are shown as dotted lines. The dotted lines without a donor group represent relatively long hydrogen bonds (86-89\% $\Sigma_{\mathrm{vdw}}$ ) to phenylene $\mathrm{C}-\mathrm{H}$ donors of an adjacent receptor.
We attempted to crystallise $\mathbf{8}^{\mathrm{H4+}}$ with sulfate, TP2- and $\mathbf{5}^{4-}$. In one case, we were able to obtain crystals, of $8^{\mathrm{H}} \cdot\left(\mathrm{SO}_{4}\right)_{2}$. The asymmetric unit contains a complete molecule of $8^{\mathrm{H} 4+}$ as well as two sulfate anions (Figure 7), one of which was modelled as disordered over two positions. Areas of diffuse electron density are present, which we attribute to poorly resolved disordered solvent molecules. This electron density was included in the model using PLATON-SQUEEZE. 57 Disappointingly, the sulfate anions are not located in the expected binding clefts: instead seven of the eight triazole groups adopt an anti conformation and the anions are located in "supramolecular hugs" in pockets close to the tetraphenylmethane part of the receptor. Hydrogen bonds are formed between the anions and triazole $\mathrm{C}-\mathrm{H}$ donors ( $\mathrm{H}-0$ : $2.17-2.66 \AA$, 81-98\% $\left.\Sigma_{\mathrm{vaw}}\right)$ as well as "exterior" pyridinium hydrogen atoms (i.e. the group ortho to the pyridinium nitrogen atom, $\mathrm{H}-0$ : $2.18-2.53 \AA$, $\left.81-94 \% \Sigma_{v a w}\right)$. One of the anions also participates in relatively long hydrogen bonds with phenyl groups from a phenyl-pyridinium motif $(\mathrm{H}-\mathrm{O}$ : 2.46, $\left.2.53 \AA, 91,94 \% \Sigma_{\mathrm{vaw}}\right)$. While the targeted porous structure was not obtained due to the unexpected location of the anions, there are still moderate size voids in the structure, which we attribute to the inability of the large and bulky $8^{\mathrm{H} 4+}$ cations to pack efficiently.

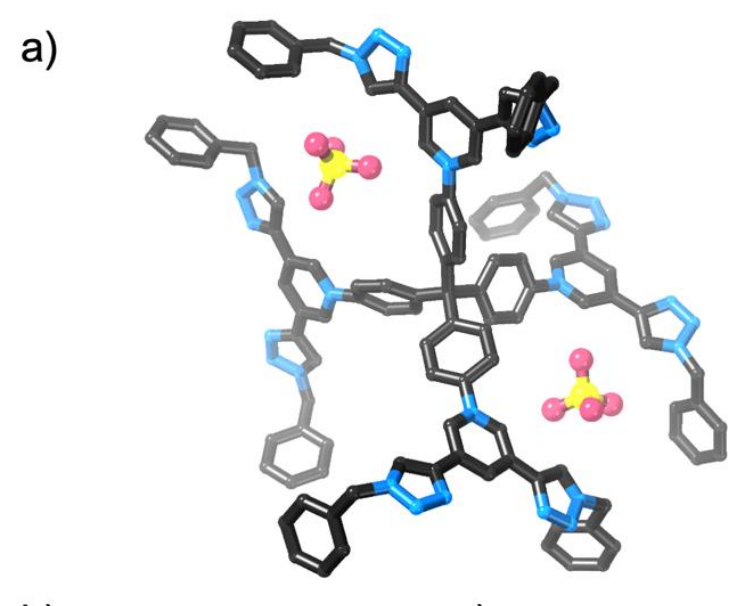

b)

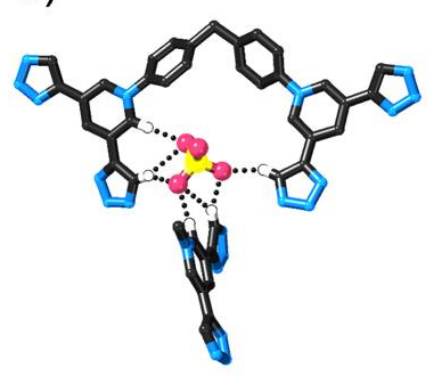

c)

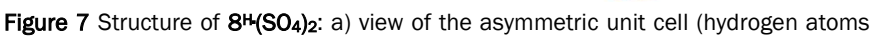
omitted), b and c) view of the hydrogen bonding environments around each independent $\mathrm{SO}_{4}{ }^{2-}$ anion (only hydrogen atoms involved in hydrogen bonding shown, hydrogen bonds shown as dotted lines). PLATON-SQUEEZE57 was used. 


\section{Conclusions}

We have prepared a series of new ditopic and tetratopic hydrogen and halogen bonding receptors, including a family of rigid receptors prepared using Zincke methodology. We were not able to prepare the desired anion templated 1D and 3D networks using these, which may be due to a number of factors. Perhaps the most important appears to be the propensity of the triazole groups to rotate such that their $\mathrm{C}-\mathrm{H}$ or $\mathrm{C}-\mathrm{I}$ group does not point towards the anion binding cleft. It is conceivable that additional functionality could be added to preorganise the triazole groups to point towards the cleft, 63 although this would be synthetically challenging for the systems used in this work. Additionally it is possible that the hexyl and benzyl substituents (necessary due to synthetic considerations) are not ideal for framework formation.

Crystal structures reveal that iodo-btp derivatives form very short halogen bonds with halide anions. The strength of these halogen bonding interactions was also apparent in difficulties achieving complete anion exchange of bromide salts of these receptors with $\mathrm{PF}_{6}{ }^{-}$, and by the observation of a chloride salt of a receptor where the chloride anion appears to have arisen from decomposition of dichloromethane solvent.

Generally, it appears that the use of btp motifs to prepare 3D supramolecular frameworks may be challenging. A possible alternative strategy would be to use the 3,5-pyridinium-bis(amide) motif popularised by Beer, ${ }^{64}$ which contains amide groups in place of triazoles. While this would be limited to hydrogen bonded materials rather than halogen/chalcogen bonds, amides are more potent hydrogen bond donors than triazoles and significantly smaller substituents (e.g. $\mathrm{H}, \mathrm{Me}$ ) can be installed at the amide group. It is hoped that the Zincke conditions developed in this work might prove useful for these or other systems.

\section{Experimental}

\section{X-ray crystallography}

Crystal structures of $\quad 1^{\mathrm{H}} \mathrm{Bn}, \quad 2^{\mathrm{H}_{\text {hex }}}\left(\mathrm{HSO}_{4}\right)_{2}, \quad 2^{\prime} \mathrm{Bn}^{\prime} \cdot\left(\mathrm{HSO}_{4}\right)_{2}$, $2^{2} \mathrm{Bn} \cdot\left(\mathrm{HSO}_{4}\right)_{1.2} \cdot \mathrm{Bro}_{0.8}, 2^{\mathrm{I}} \mathrm{Bn}^{-} \mathrm{Cl}_{2}, 7^{\mathrm{H}_{-}} \cdot \mathrm{Cl}_{2}$ and $8^{\mathrm{H}-\left(\mathrm{SO}_{4}\right)_{2}}$ were obtained. These were collected using either an Oxford Diffraction Supernova diffractometer, or beamlines MX165 or MX266 of the Australian Synchrotron. Data collected using the Supernova diffractometer were collected at $150 \mathrm{~K}$ and raw frame data (including data reduction, interframe scaling, unit cell refinement and absorption corrections) were processed using CrysAlis Pro. ${ }^{67}$ Data collected using synchrotron radiation were collected at $100 \mathrm{~K}$ and raw frame data were processed using XDS. ${ }^{68}$ Structures were solved using either Superflip69 or SHELXT70 and refined using either CRYSTALS ${ }^{71}$ or OLEX2. ${ }^{72}$ Full crystallographic data in CIF format are provided as Supporting Information (CCDC Numbers: 2130560 - 2130566). Refinements of individual structures are discussed in the Supporting Information, and crystallographic data are summarized in Table S1.

\section{Synthesis}

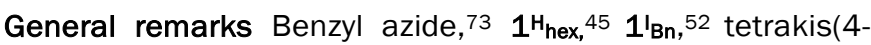
tolyl)silane, ${ }^{74}$ tetrakis(4-aminophenyl)methane, 75 TBA $2 \cdot{ }^{7} 76$ and TBA 4.577 were prepared as previously described. THF was dried by distillation from sodium. Other chemicals were bought from commercial suppliers and used as received. An optimised procedure for the synthesis of 3,5-diethynylpyridine is provided in the Supporting Information, as well as details of the preparation of selenium containing receptors. Details of instrumentation and copies of spectra are provided as supporting information.

$1^{\mathrm{H}_{\mathrm{Bn}}}$ : 3,5-Diethynylpyridine (1.00 g, $7.81 \mathrm{mmol}, 1.0$ equiv.) was dissolved in 4:1 DMF: $\mathrm{H}_{2} \mathrm{O}(100 \mathrm{~mL})$. Sodium azide $(1.22$ g, $18.8 \mathrm{mmol}, 2.4$ equiv.), sodium carbonate ( $0.830 \mathrm{~g}, 7.81$ mmol, 1.0 equiv.), ascorbic acid (1.38 g, $7.81 \mathrm{mmol}, 1.0$ equiv.) and copper(II) sulfate pentahydrate (0.12 g, 0.49 mmol, 0.063 equiv.) were added, followed by benzyl bromide ( $2.1 \mathrm{~mL}, 17 \mathrm{mmol}, 2.2$ equiv.) and the solution was heated to $80{ }^{\circ} \mathrm{C}$ under a nitrogen atmosphere for 3 days. The resulting brown solution was cooled and ethyl acetate $(75 \mathrm{~mL})$ and an aqueous $\mathrm{EDTA} / \mathrm{K}_{2} \mathrm{CO}_{3}$ solution $(50 \mathrm{~mL})$ were added. The organic layer was taken, washed with water $(2 \times 50 \mathrm{~mL})$ and brine $(2 \times 50 \mathrm{~mL})$ and dried $\left(\mathrm{MgSO}_{4}\right)$. It was concentrated under reduced pressure to give a yellow solid, which was purified by column chromatography (95:5 dichloromethane:methanol) to give $1^{\mathrm{H}_{\mathrm{Bn}}}$ as a white powder. Yield: $2.6 \mathrm{~g}$ (6.5 mmol, 84\%).

${ }_{1} \mathrm{H}$ NMR (d6-DMSO): $9.01(\mathrm{~d}, J=2.1 \mathrm{~Hz}, 2 \mathrm{H}), 8.84(\mathrm{~s}, 2 \mathrm{H})$, $8.66(\mathrm{t}, J=2.1 \mathrm{~Hz}, 1 \mathrm{H}), 7.33-7.43(\mathrm{~m}, 1 \mathrm{HH}), 5.69(\mathrm{~s}, 4 \mathrm{H})$ ppm. ${ }^{13} \mathrm{C}$ NMR (d6-DMSO): 145.6, 143.6, 135.8, 128.8, $128.5,128.3,128.0,126.8,122.6,53.2$ ppm. HRESI-MS (pos.): 394.1775 , calc. for $\left[\mathrm{C}_{23} \mathrm{H}_{19} \mathrm{~N}_{7} \cdot \mathrm{H}\right]^{+}=394.1776 \mathrm{Da}$.

$2^{\mathrm{H}_{\text {hex }}} \mathrm{Br}_{2}$ : A suspension of $1^{\mathrm{H}_{\text {hex }}}(0.025 \mathrm{~g}, 0.066 \mathrm{mmol}, 2.0$ equiv.) and 1,4-bis(bromomethyl)benzene (0.0086 g, 0.033 mmol, 1.0 equiv.) in acetonitrile $(2 \mathrm{~mL})$ was heated at reflux under $\mathrm{N}_{2}$ overnight. The suspension was cooled to room temperature and the resulting precipitate was isolated via filtration, washed with acetonitrile $(3 \times 5 \mathrm{~mL})$, and air dried to give ${ }^{2} \mathrm{H}_{\text {hex }} \mathrm{Br}_{2}$ as a white powder. Yield: $0.021 \mathrm{~g}(0.020 \mathrm{mmol}$, $64 \%)$.

${ }_{1}^{1} \mathrm{H}$ NMR (d6-DMSO): 9.67 (s, 4H), 9.31 (br. s, 2H), 8.99 (br. $\mathrm{s}, 4 \mathrm{H}), 7.74(\mathrm{~s}, 4 \mathrm{H}), 5.99(\mathrm{~s}, 4 \mathrm{H}), 4.50(\mathrm{t}, J=7.0 \mathrm{~Hz}, 8 \mathrm{H})$, $1.83-1.90(\mathrm{~m}, 8 \mathrm{H}), 1.23-1.32(\mathrm{~m}, 24 \mathrm{H}), 0.85(\mathrm{t}, J=6.8 \mathrm{~Hz}$, $12 \mathrm{H}$ ) ppm. ${ }^{13} \mathrm{C}$ NMR (d6-DMSO): 140.4, 139.5, 136.0, 135.3, 131.9, 129.6, 124.7, 63.3, 50.0, 30.6, 29.5, 25.4, 21.9, 13.9 ppm. HRESI-MS (pos.): 433.2946 , calc. for $\left[\mathrm{C}_{50} \mathrm{H}_{70} \mathrm{~N}_{14}\right]^{2+}$ $=433.2948 \mathrm{Da}$.

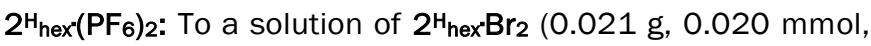
1.0 equiv) in DMF $(7 \mathrm{~mL})$ was added $\mathrm{NH}_{4} \mathrm{PF}_{6}(0.040 \mathrm{~g}, 0.25$ mmol, 13 equiv). Methanol ( $3 \mathrm{~mL}$ ) and water $(1 \mathrm{~mL})$ were added to give a clear solution. Water $(30 \mathrm{~mL})$ was then added causing the formation of a white suspension. The solid was 
isolated by centrifugation and dried in vacuo to give $2 \mathrm{H}_{\text {hex }}\left(\mathrm{PF}_{6}\right)_{2}$ as a white powder. Yield: $0.018 \mathrm{~g}(0.016 \mathrm{mmol}$, $78 \%)$.

${ }^{1} \mathrm{H}$ NMR (d6-acetone): 9.62 (d, $J=1.4 \mathrm{~Hz}, 4 \mathrm{H}$ ), 9.35 (t, $J=$ $1.4 \mathrm{~Hz}, 2 \mathrm{H}), 8.85(\mathrm{~s}, 4 \mathrm{H}), 7.92(\mathrm{~s}, 4 \mathrm{H}), 6.27(\mathrm{~s}, 4 \mathrm{H}), 4.56(\mathrm{t}, J$ $=7.1 \mathrm{~Hz}, 8 \mathrm{H}), 1.94-2.02(\mathrm{~m}, 8 \mathrm{H}), 1.25-1.39(\mathrm{~m}, 24 \mathrm{H}), 0.87$ (t, $J=7.1 \mathrm{~Hz}, 12 \mathrm{H}) \mathrm{ppm} .{ }^{19} \mathrm{~F}$ NMR (d6-acetone): $-72.3(\mathrm{~d}, J=$ $708 \mathrm{~Hz}$ ) ppm. ${ }^{31} \mathrm{P}$ NMR (d6-acetone): -144.2 (hept., $J=708$ $\mathrm{Hz}$ ) ppm. ESI-MS (pos.): 1011.6, calc. for $\left[\left(\mathrm{C}_{50} \mathrm{H}_{70} \mathrm{~N}_{14}\right)^{2+} \cdot\left(\mathrm{PF}_{6}\right)^{-}\right.$ ]$^{+}=1011.6 \mathrm{Da}$.

$2 \mathrm{H}_{\mathrm{Bn}} \cdot \mathrm{Br}_{2}$ : A suspension of $1^{\mathrm{H}_{\mathrm{Bn}}}(0.25 \mathrm{~g}, 0.64 \mathrm{mmol}, 2.0$ equiv $)$ and 1,4-bis(bromomethyl)benzene $(0.084 \mathrm{~g}, 0.32 \mathrm{mmol}, 1.0$ equiv) in acetonitrile $(5 \mathrm{~mL})$ was heated at reflux under $\mathrm{N}_{2}$ overnight. The suspension was cooled to room temperature and the resulting precipitate was collected by filtration, washed with cold acetonitrile $(3 \times 10 \mathrm{~mL})$, and air-dried to give $2 \mathrm{H}_{\mathrm{Bn}} \cdot \mathrm{Br}_{2}$ as a beige powder. Yield: $0.310 \mathrm{~g}(0.295 \mathrm{mmol}, 93 \%)$.

1H NMR (d6-DMSO): 9.72 (br. s), 9.34 (br. s, 2H), 9.06 (s, $4 \mathrm{H}), 7.73(\mathrm{~s}, 4 \mathrm{H}), 7.34-7.43(\mathrm{~m}, 2 \mathrm{OH}), 5.99(\mathrm{~s}, 4 \mathrm{H}), 5.77(\mathrm{~s}$, $8 \mathrm{H}) \mathrm{ppm} .{ }^{13} \mathrm{C}$ NMR (d6-DMSO): 140.8, 139.7, 136.2, 135.4, 135.2, 131.6, 129.5, 128.9, 128.5, 128.1, 124.9, 63.2, 53.5 ppm. HRESI-MS (pos.) 445.2004 , calc. for $\left[\mathrm{C}_{54} \mathrm{H}_{46} \mathrm{~N}_{14}\right]^{2+}$ $=445.2009 \mathrm{Da}$.

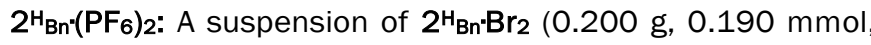
1.0 equiv.) was suspended in methanol $(20 \mathrm{~mL})$ and heated to $60{ }^{\circ} \mathrm{C}$. DMF $(10 \mathrm{~mL})$ was added causing everything to dissolve to give a pale yellow solution. $\mathrm{NH}_{4} \mathrm{PF}_{6}(0.200 \mathrm{~g}, 1.23$ mmol, 6.5 equiv.) in water $(5 \mathrm{~mL})$ was added, followed by more water until a precipitate started to form ( $15 \mathrm{~mL}$ more). The mixture was placed in an ice bath for an hour, and the white powder isolated by filtration and washed with water (3 $\times 10 \mathrm{~mL})$ and then diethyl ether $(3 \times 10 \mathrm{~mL})$ and then dried under vacuum. Yield: $0.205 \mathrm{~g}(0.174 \mathrm{mmol}, 91 \%)$.

1H NMR (d6-acetone): $9.58(\mathrm{~s}, 4 \mathrm{H}), 9.33(\mathrm{~s}, 2 \mathrm{H}), 8.78(\mathrm{~s}$, $4 \mathrm{H}), 7.84(\mathrm{~s}, 4 \mathrm{H}), 7.37-7.44(\mathrm{~m}, 2 \mathrm{OH}), 6.22(\mathrm{~s}, 4 \mathrm{H}), 5.76(\mathrm{~s}$, $8 \mathrm{H})$ ppm. ${ }^{19} \mathrm{~F}$ NMR (d 6 -acetone): $-72.3(\mathrm{~d}, J=708 \mathrm{~Hz}) \mathrm{ppm}$. 31P NMR (d6-acetone): -144.2 (hept., $J=708 \mathrm{~Hz}$ ) ppm. ESIMS (pos.): 1035.6 , calc. for $\left[\left(\mathrm{C}_{54} \mathrm{H}_{46} \mathrm{~N}_{14}\right)^{2+\cdot(}\left(\mathrm{PF}_{6}\right)^{-}\right]^{+}=1035.4$ Da.

${ }^{2}{ }_{\mathrm{Bn}} \mathrm{Br}_{2}$ : A suspension of $1^{\prime} \mathrm{Bn}(0.200 \mathrm{~g}, 0.310 \mathrm{mmol}, 2.0$ equiv.) and 1,4-bis(bromomethyl)benzene (0.0409 g, 0.155 mmol, 1.0 equiv.) in acetonitrile $(12 \mathrm{~mL})$ was heated at reflux under $\mathrm{N}_{2}$ overnight. The suspension was cooled to room temperature and the resulting cream powder isolated by filtration, washed with acetonitrile $(3 \times 10 \mathrm{~mL})$ and diethyl ether $(10 \mathrm{~mL})$ and dried under vacuum. Yield: $0.192 \mathrm{~g}(0.123$ $\mathrm{mmol}, 80 \%)$.

1H NMR (d6-DMSO): 9.74 (s, 4H), 9.69 (s, 2H), 7.77 (s, 2H), 7.31-7.40 (m, 12H), $7.25(\mathrm{~d}, J=7.0 \mathrm{~Hz}, 8 \mathrm{H}), 6.10(\mathrm{~s}$, $4 \mathrm{H}), 5.79$ (s, 8H) ppm. ${ }^{13} \mathrm{C}$ NMR (d6-DMSO): 143.3, 141.2, 136.7, 135.3, 134.9, 131.3, 130.0, 128.8, 128.2, 127.4, 89.6, 63.4, 53.6 ppm. HRESI-MS (pos.): 696.9934 , calc. for $\left[\mathrm{C}_{54} \mathrm{H}_{42} \mathrm{~N}_{14} \mathrm{I}_{4}\right]^{2+}=696.9942 \mathrm{Da}$. $2^{\prime}{ }_{B n} \cdot\left(B F_{4}\right)_{2}:$ A solution of $\mathrm{AgBF}_{4}(0.0243 \mathrm{~g}, 0.124 \mathrm{mmol}, 2.0$ equiv.) was added to a solution of ${ }^{2}{ }^{\prime} \mathrm{Bn}^{n} \cdot \mathrm{Br}_{2}(0.097 \mathrm{~g}, 0.062$ mmol, 1.0 equiv.) in DMF (2 mL) and stirred at room temperature under $\mathrm{N}_{2}$ with the exclusion of light for 2 hours. The resulting suspension was filtered through a small plug of celite, washing through with more DMF $(3 \mathrm{~mL})$. The filtrate was concentrated under vacuum to give a dark solid. Acetone ( $3 \mathrm{~mL}$ ) was added, causing the formation of a brown solid, which was removed via filtration. The yellow filtrate was concentrated under vacuum and the resulting yellow solid dissolved in acetone $(5 \mathrm{~mL})$ and precipitated by the addition of diethyl ether $(45 \mathrm{~mL})$. The flask was cooled in the freezer, and then the powder isolated by filtration and washed with diethyl ether $(3 \times 10 \mathrm{~mL})$ and dried in vacuo to give $2^{\prime}{ }^{\prime} n^{-} \cdot\left(B_{4}\right)_{2}$ as an off-white powder. Yield: $0.047 \mathrm{~g}(0.030 \mathrm{mmol}, 48 \%)$.

${ }^{1} \mathrm{H}$ NMR (d6-acetone): 9.80 (t, $\left.J=1.6 \mathrm{~Hz}, 4 \mathrm{H}\right), 9.72$ (d, $J=$ $1.6 \mathrm{~Hz}, 2 \mathrm{H}), 7.97(\mathrm{~s}, 4 \mathrm{H}), 7.32-7.41(\mathrm{~m}, 2 \mathrm{OH}), 6.37(\mathrm{~s}, 4 \mathrm{H})$, 5.83 (s, 8H) ppm. 19F NMR (d6-acetone): -151.26 (s), 151.31 (s) ppm. ESI-MS (pos.): 1482.1, calc. for $\left[\left(\mathrm{C}_{54} \mathrm{H}_{42} \mathrm{~N}_{14} \mathrm{I}_{4}\right)^{2+\cdot}\left(\mathrm{BF}_{4}\right)^{-}\right]^{+}=1482.0 \mathrm{Da}$.

3: This compound has been reported previously by a similar method but using $\mathrm{CCl}_{4}$ as solvent, ${ }^{78}$ but no NMR data were provided.

A suspension of tetrakis(4-tolyl)silane $(0.200 \mathrm{~g}, 0.508 \mathrm{mmol}$, 1.0 equiv.), $\mathrm{N}$-bromosuccinimide $(0.769 \mathrm{~g}, 4.47 \mathrm{mmol}, 8.8$ equiv.) and benzoyl peroxide (0.026 g, $0.10 \mathrm{mmol}, 0.20$ equiv.) in chloroform $(20 \mathrm{ml})$ was heated to reflux for 64 hours. It was cooled to room temperature and then taken to dryness under reduced pressure to give an orange solid. Methanol $(15 \mathrm{~mL})$ was added and the suspension stirred for 30 minutes. The resulting white powder was isolated by filtration, washed with methanol $(3 \times 5 \mathrm{~mL})$ and air-dried to give 3. Yield: $0.108 \mathrm{~g}(0.152 \mathrm{mmol}, 30 \%)$.

${ }_{1} \mathrm{H}$ NMR $\left(\mathrm{CDCl}_{3}\right): 7.51(\mathrm{~d}, J=8.1 \mathrm{~Hz}, 8 \mathrm{H}), 7.41(\mathrm{~d}, J=8.1$ $\mathrm{Hz}, 8 \mathrm{H}), 4.50(\mathrm{~s}, 8 \mathrm{H}) \mathrm{ppm} .{ }^{13} \mathrm{C} \mathrm{NMR}\left(\mathrm{CDCl}_{3}\right): 139.6,136.9$, 134.0, 128.7, 33.3 ppm. HRESI-MS (pos.) 703.8383, calc. for $\left[\mathrm{C}_{28} \mathrm{H}_{24} \mathrm{SiBr}_{4}\right]^{+}=703.8381 \mathrm{Da}$.

$4^{\mathrm{H} \cdot \mathrm{Br}_{4}: 1^{\mathrm{H}} \mathrm{Bn}}(0.033 \mathrm{~g}, 0.085 \mathrm{mmol}, 4.0$ equiv.) and 3 (0.015 $\mathrm{g}, 0.021 \mathrm{mmol}, 1.0$ equiv) were dissolved in acetonitrile (5 $\mathrm{mL}$ ) and heated to reflux for 3 days under $\mathrm{N}_{2}$ resulting in the formation of an orange precipitate. The supernatant was decanted and the resulting solid was dried under vacuum to give the pure product as a pale orange powder. Yield: 0.032 g (0.14 mmol, 66\%).

${ }^{1} \mathrm{H}$ NMR (d6-DMSO): 9.69 (s, 8H), 9.34 (s, 4H), 9.03 (s, $4 \mathrm{H}), 9.02(\mathrm{~s}, 4 \mathrm{H}), 7.61(\mathrm{~d}, J=7.0 \mathrm{~Hz}, 8 \mathrm{H}), 7.35-7.50(\mathrm{~m}$,

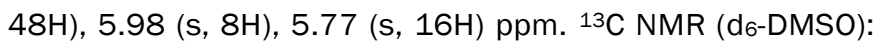
$140.8,139.7,136.4,136.2,136.1,135.7,135.3,134.3$, 133.6, 131.6, 128.9, 128.5, 128.2, 128.1, 124.9, 63.3, 53.5 ppm. HRESI-MS (pos.): 490.4616, calc. for $\left[\mathrm{C}_{120} \mathrm{H}_{100} \mathrm{~N}_{28} \mathrm{Si}^{4+}=490.4614 \mathrm{Da}\right.$.

"Doubling" of peaks belonging to the pyridinium and triazole resonances is apparent in the ${ }^{1 H}$ NMR and ${ }^{13} \mathrm{C} N M R$ spectra, which we attribute to hindered rotation. 
4H-(PF6)4: Separately, $4{ }^{H} \cdot \mathrm{Br}_{4}$ (0.030 g, $0.013 \mathrm{mmol}, 1.0$ equiv.) and $\mathrm{NH}_{4} \mathrm{PF}_{6}(0.017 \mathrm{~g}, 0.10 \mathrm{mmol}, 8.0$ equiv.) were dissolved in 2:1 methanol:DMF ( $3 \mathrm{~mL}$ each). The two solutions were mixed and then water $(4 \mathrm{~mL})$ was added causing the solution to become cloudy. The precipitate was isolated by centrifugation, and the resulting solid suspended in water, sonicated, and then isolated by centrifugation. The resulting pale yellow powder was dried in vacuo to give $4 \mathrm{H} \cdot\left(\mathrm{PF}_{6}\right)_{4}$. Yield: $0.020 \mathrm{~g}(0.0079 \mathrm{mmol}, 60 \%)$.

1H NMR (d6-DMSO): 9.62 (s, 4H), $9.61(\mathrm{~s}, 4 \mathrm{H}), 9.31$ (s, $2 \mathrm{H}), 9.29(\mathrm{~s}, 2 \mathrm{H}), 8.93(\mathrm{~s}, 4 \mathrm{H}), 8.92(\mathrm{~s}, 4 \mathrm{H}), 7.32-7.60(\mathrm{~m}$, $56 \mathrm{H}), 5.95$ (s, 8H), 5.76 (s, 16H) ppm. ${ }^{19} \mathrm{~F}$ NMR (d6-DMSO): $-72.3(\mathrm{~d}, J=711 \mathrm{~Hz}) \mathrm{ppm}$. ${ }^{31 \mathrm{P}} \mathrm{NMR}$ ( $\mathrm{d}_{6}$-DMSO): -144.2 (hept., $J=711 \mathrm{~Hz}$ ) ppm. ESI-MS (pos.): 1126.2, calc. for

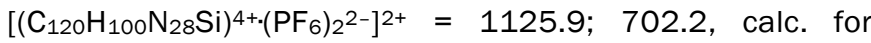
$\left[\left(\mathrm{C}_{120} \mathrm{H}_{100} \mathrm{~N}_{28} \mathrm{Si}\right)^{4+\cdot}\left(\mathrm{PF}_{6}\right)^{-}\right]^{3+}=702.3 \mathrm{Da}$.

"Doubling" of peaks belonging to the pyridinium and triazole resonances is apparent in the ${ }^{1} H$ NMR spectrum, which we attribute to hindered rotation.

4'-Br4: 1'Bn (0.092 g, $0.14 \mathrm{mmol}, 4.0$ equiv.) and 3 (0.025 g, $0.036 \mathrm{mmol}, 1.0$ equiv.) were suspended in acetonitrile and heated to reflux for 3 days under $\mathrm{N}_{2}$. The resulting light brown precipitate was isolated by filtration, washed with acetonitrile $(3 \times 10 \mathrm{~mL})$ and diethyl ether $(10 \mathrm{~mL})$ and dried in vacuo to give $4 \cdot \mathrm{Br}_{4}$ as a pale brown powder. Yield: $0.075 \mathrm{~g}(0.023$ $\mathrm{mmol}, 64 \%)$.

1H NMR (d6-DMSO): 9.75 (s, 8H), $9.68(\mathrm{~s}, 4 \mathrm{H}), 7.66$ (d, $J=$ $7.6 \mathrm{~Hz}, 8 \mathrm{H}), 7.53(\mathrm{~d}, J=7.6 \mathrm{~Hz}, 8 \mathrm{H}), 7.19-7.41(\mathrm{~m}, 4 \mathrm{OH})$, 6.09 (s, 8H), 5.80 (s, 16H) ppm. ${ }^{13} \mathrm{C}$ NMR (d6-DMSO): 143.3, $141.3,136.6,135.8,134.9,131.3,128.8,128.6,128.5$, 128.2, 127.5, 127.4, 89.1, 63.6, 53.7 ppm. HRESI-MS (pos.): 742.0035 , calc. for $\left[\mathrm{C}_{120} \mathrm{H}_{92} \mathrm{~N}_{28} \mathrm{Sil}_{8}\right]^{4+}=742.0041 \mathrm{Da}$.

4l-(BF4)4: A solution of $\mathrm{AgBF}_{4}(0.0064 \mathrm{~g}, 0.033 \mathrm{mmol}, 4.0$ equiv.) in DMF ( $1 \mathrm{~mL}$ ) was added to a solution of $4 \mathrm{H} \cdot \mathrm{Br}_{4}(0.027$ $\mathrm{g}, 0.0083 \mathrm{mmol}, 1.0$ equiv.) in DMF ( $3 \mathrm{~mL}$ ) and the mixture stirred in the dark under $\mathrm{N}_{2}$ for 2 hours. The resulting grey suspension was filtered through a short plug of celite, and washed with further DMF $(6 \mathrm{~mL})$. The resulting orange solution was taken to dryness under reduced pressure and the solid was sonicated in methanol $(5 \mathrm{~mL})$. This solid was isolated via filtration and washed with methanol $(3 \times 5 \mathrm{~mL})$ and diethyl ether to give a brown crystalline product. Yield: $0.018 \mathrm{~g}(0.0053 \mathrm{mmol}, 64 \%)$.

1H NMR (d6-DMSO): 9.76 (s, 4H), $9.74(\mathrm{~s}, 4 \mathrm{H}), 9.62$ (s, $4 \mathrm{H}), 7.67(\mathrm{~d}, J=7.5 \mathrm{~Hz}, 8 \mathrm{H}), 7.52(\mathrm{~d}, J=7.5 \mathrm{~Hz}, 8 \mathrm{H}), 6.07$ (s, 8H), 5.81 (s, 16H) ppm. 19F NMR (d 6 -DMSO): -148.3 (s), 148.2 (s) ppm. ESI-MS (pos.): 1571.6, calc. for $\left[\left(\mathrm{C}_{120} \mathrm{H}_{92} \mathrm{~N}_{28} \mathrm{Sil}_{8}\right)^{4+} \cdot\left(\mathrm{BF}_{4}\right)_{2}{ }^{2-}\right]^{2+}=1571.5 ; 1018.7$, calc, for $\left[\left(\mathrm{C}_{120} \mathrm{H}_{92} \mathrm{~N}_{28} \mathrm{Sil}_{8}\right)^{4+\cdot}\left(\mathrm{BF}_{4}\right)^{-}\right]^{3+}=1018.7 \mathrm{Da}$.

"Doubling" of peaks belonging to the pyridinium resonances is apparent in the ${ }^{1 H}$ NMR spectrum, which we attribute to hindered rotation.
$6 \mathrm{H} \cdot \mathrm{Cl}$ : In a heavy-walled glass vial behind a blast shield, $1^{\mathrm{H}_{\mathrm{Bn}}}$ (0.500 g, $1.27 \mathrm{mmol}, 1.0$ equiv.) and 1-chloro-2,4dinitrobenzene (1.54 g, $7.63 \mathrm{mmol}, 6.0$ equiv.) were suspended in ethanol $(6 \mathrm{~mL})$ and heated to $120{ }^{\circ} \mathrm{C}$ for 10 days. During this time the reaction changed from yellow to orange-red with some dark oily residue forming. The reaction was cooled to room temperature, filtered to remove the dark residue, and the filtrate was taken to dryness under reduced pressure to give an orange solid. This was dissolved in acetone $(50 \mathrm{~mL})$ and filtered to remove an insoluble white solid. Diethyl ether $(150 \mathrm{~mL})$ was added to the filtrate resulting in the precipitation of a yellow powder. The mixture was cooled in the freezer overnight and then the yellow powder was isolated via filtration, washed with diethyl ether $(3 \times 10 \mathrm{~mL})$ and dried in vacuo to give $6^{\mathrm{H}} \mathrm{Cl}$. Yield: $0.267 \mathrm{~g}$ (0.448 mmol, 35\%).

1H NMR (d6-DMSO): $9.87(\mathrm{~d}, J=1.6 \mathrm{~Hz}, 2 \mathrm{H}), 9.65(\mathrm{t}, J=$ $1.6 \mathrm{~Hz}, 1 \mathrm{H}), 9.15(\mathrm{~d}, J=2.5 \mathrm{~Hz}, 1 \mathrm{H}), 9.03(\mathrm{~s}, 2 \mathrm{H}), 9.01(\mathrm{dd}, J$ $=8.7,2.5 \mathrm{~Hz}, 1 \mathrm{H}), 8.48(\mathrm{~d}, J=8.7 \mathrm{~Hz}, 1 \mathrm{H}), 7.35-7.44(\mathrm{~m}$, $10 \mathrm{H}), 5.79$ (s, 4H) ppm. ${ }^{13} \mathrm{C}$ NMR (d6-DMSO): 149.4, 143.1, $141.1,140.6,138.7,138.4,135.4,132.0,131.3,130.4$, 129.2, 128.7, 128.4, 125.4, 121.6, 53.7 ppm. HRESI-MS (pos.): 560.1794 , calc. for $\left[\mathrm{C}_{29} \mathrm{H}_{22} \mathrm{~N}_{9} \mathrm{O}_{4}\right]^{+}=560.1795 \mathrm{Da}$.

6l-Cl: A mixture of $1^{1} \mathrm{Bn}(0.528 \mathrm{~g}, 0.818 \mathrm{mmol}, 1.0$ equiv. $)$ and 1-chloro-2,4-dinitrobenzene ( $1.66 \mathrm{~g}, 8.20 \mathrm{mmol}, 10$ equiv.) in 1:1 ethanol:DMF (90 mL) was heated to $95{ }^{\circ} \mathrm{C}$ in a heavywalled vial behind a blast shield for 10 days. The resulting yellow suspension was cooled to room temperature, filtered to remove an insoluble solid, and the filtrate taken to dryness under reduced pressure to give a yellow oil. This was suspended in acetone $(100 \mathrm{~mL})$, stirred for an hour and then filtered to remove an insoluble solid. The filtrate was taken to dryness under reduced pressure, methanol (50 mL) was added and the suspension again filtered to remove an insoluble solid. The filtrate was again taken to dryness under reduced pressure and then the residue dissolved in methanol $(10 \mathrm{~mL})$ and diethyl ether $(250 \mathrm{~mL})$ added resulting in the precipitation of a yellow solid. The mixture was left in a freezer overnight and then the solid isolated by filtration. This was sonicated in dichloromethane $(20 \mathrm{~mL})$ and the solid again isolated by filtration. Taking this solid up in methanol $(2 \mathrm{~mL})$ and precipitating with diethyl ether $(10 \mathrm{~mL})$ finally gave pure product, which was isolated by filtration, washed with diethyl ether $(3 \times 5 \mathrm{~mL})$ and dried in vacuo to give $6 \mathrm{l} \cdot \mathrm{Cl}$. Yield: 0.049 g $(0.060 \mathrm{mmol}, 7 \%)$.

${ }^{1} \mathrm{H}$ NMR (d6-DMSO): 10.08 (t, $\left.J=1.6 \mathrm{~Hz}, 1 \mathrm{H}\right), 9.95$ (d, $J=$ $1.6 \mathrm{~Hz}, 2 \mathrm{H}), 9.14(\mathrm{~d}, J=2.5 \mathrm{~Hz}, 1 \mathrm{H}), 8.99(\mathrm{dd}, J=8.7,2.5 \mathrm{~Hz}$, $1 \mathrm{H}), 8.52(\mathrm{~d}, J=8.7 \mathrm{~Hz}, 1 \mathrm{H}), 7.26-7.43(\mathrm{~m}, 1 \mathrm{HH}), 5.83(\mathrm{~s}$, $4 \mathrm{H})$ ppm. ${ }^{13} \mathrm{C}$ NMR (d6-DMSO): 149.2, 143.2, 143.1, 142.4, $138.7,138.3$, 134., 131.9, 130.9, 130.0, 128.7, 128.1, 127.3, 121.0, 90.6. 53.6 ppm. HRESI-MS (pos.): 811.9730, calc. for $\left.\left[\mathrm{C}_{29} \mathrm{H}_{20} \mathrm{~N}_{9} \mathrm{O}_{4}\right]_{2}\right]^{+}=811.9728 \mathrm{Da}$.

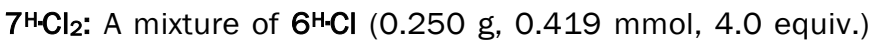
and para-phenylenediamine $(0.011 \mathrm{~g}, 0.11 \mathrm{mmol}, 1.0$ equiv.) were dissolved in 1:1 ethanol:water $(24 \mathrm{~mL})$. The resulting 
orange solution was heated at $80{ }^{\circ} \mathrm{C}$ under $\mathrm{N}_{2}$ for 5 days. It was then taken to dryness under reduced pressure to give a yellow solid. This was suspended in acetonitrile $(10 \mathrm{~mL})$ and sonicated for 10 minutes. The resulting yellow powder was isolated by filtration, washed with acetonitrile $(3 \times 10 \mathrm{~mL})$ and then diethyl ether $(10 \mathrm{~mL})$ and dried in vacuo to give $7 \mathrm{H}^{-} \mathrm{Cl}_{2}$. Yield: $0.078 \mathrm{~g}(0.084 \mathrm{mmol}, 80 \%)$.

1H NMR (d 6 -DMSO): $9.70(\mathrm{~d}, J=1.4 \mathrm{~Hz}, 4 \mathrm{H}), 9.63(\mathrm{t}, J=$ $1.4 \mathrm{~Hz}, 2 \mathrm{H}), 9.15$ (s, 4H), 8.44 (s, 4H), 7.36-7.46 (m, 2OH), 5.82 (s, 8H) ppm. ${ }^{13} \mathrm{C}$ NMR (d6-DMSO): 144.3, 140.6, 140.1, 135.4, 131.5, 129.0, 128.5, 128.2, 126.9, 125.1, 99.5, 53.5 ppm. HRESI-MS (pos.) 431.1844 , calc. for $\left[\mathrm{C}_{53} \mathrm{H}_{42} \mathrm{~N}_{14}\right]^{2+}$ $=431.1853 \mathrm{Da}$.

$7 \mathrm{H}-\left(\mathrm{PF}_{6}\right)_{2}: 7^{\mathrm{H}-\mathrm{Cl}_{2}}(0.030 \mathrm{~g}, 0.032 \mathrm{mmol}, 1.0$ equiv.) was dissolved in methanol ( $3 \mathrm{~mL})$ with heating. A solution of $\mathrm{NH}_{4} \mathrm{PF}_{6}(0.031 \mathrm{~g}, 0.19 \mathrm{mmol}, 6.0$ equiv.) in water $(2 \mathrm{~mL})$ was added, resulting in the formation of a pale yellow precipitate. The reaction was left to stand at room temperature for 2 hours and then the solid was isolated by filtration, washed with methanol $(3 \times 5 \mathrm{~mL})$ and diethyl ether $(5 \mathrm{~mL})$ and dried in vacuo to give $7 \mathrm{H} \cdot\left(\mathrm{PF}_{6}\right)_{2}$ as a pale yellow powder. Yield: 0.027 g $(0.024 \mathrm{mmol}, 74 \%)$.

1H NMR ( $\left.\mathrm{CD}_{3} \mathrm{CN}\right): 9.37(\mathrm{t}, J=1.4 \mathrm{~Hz}, 2 \mathrm{H}), 9.32(\mathrm{~d}, J=1.4$ $\mathrm{Hz}, 4 \mathrm{H}), 8.55$ (s, 4H), $8.18(\mathrm{~s}, 4 \mathrm{H}), 7.39-7.47$ (m, 2OH), 5.71 (s, 8H) ppm. ${ }^{19} \mathrm{~F} \mathrm{NMR}\left(\mathrm{CD}_{3} \mathrm{CN}\right):-72.9(\mathrm{~d}, J=707 \mathrm{~Hz})$ ppm. ${ }^{31} \mathrm{P}$ NMR $\left(\mathrm{CD}_{3} \mathrm{CN}\right)$ : -144.7 (hept., $J=707 \mathrm{~Hz}$ ) ppm. ESI-MS (pos.): 1007.4, calc. for $\left[\left(\mathrm{C}_{52} \mathrm{H}_{42} \mathrm{~N}_{14}\right)^{2+.}\left(\mathrm{PF}_{6}\right)^{-}\right]^{+}=1007.3 \mathrm{Da}$.

7I- $\mathrm{Cl}_{2}$ : A mixture of $7 \mathrm{H} \cdot \mathrm{Cl}$ (30 mg, $0.036 \mathrm{mmol}, 4.0$ equiv.) and para-phenylenediamine ( $0.98 \mathrm{mg}, 0.0091 \mathrm{mmol}, 1.0$ equiv.) were dissolved in 1:1 ethanol:water $(4 \mathrm{~mL})$. The resulting orange solution was heated at $80{ }^{\circ} \mathrm{C}$ under $\mathrm{N}_{2}$ for 3 days during which time a yellow precipitate formed. This precipitate was isolated by filtration and suspended in acetonitrile $(5 \mathrm{~mL})$ and sonicated for 10 minutes. The resulting yellow powder was isolated by filtration, washed with acetonitrile $(3 \times 5 \mathrm{~mL})$ and then diethyl ether $(5 \mathrm{~mL})$ and dried in vacuo to give $71 \cdot \mathrm{Cl}_{2}$. Yield: $5.1 \mathrm{mg}$ (0.0036 mmol, 39\%).

1H NMR (d6-DMSO): 9.92 (t, $J=1.3 \mathrm{~Hz}, 2 \mathrm{H}), 9.72(\mathrm{~d}, J=$ $1.3 \mathrm{~Hz}, 4 \mathrm{H}), 8.45$ (s, 4H), 7.29-7.44 (m, 2OH), $5.84(\mathrm{~s}, 8 \mathrm{H})$ ppm. ${ }^{13} \mathrm{C}$ NMR (d6-DMSO): 144.6, 143.4, 141.4, 138.4, 135.0, 131.1, 128.9, 128.3, 127.6, 127.1, 89.4, 53.7ppm. HRESI-MS (pos.) 1400.9253, calc. for $\left[\left(\mathrm{C}_{52} \mathrm{H}_{38} \mathrm{~N}_{14} \mathrm{I}_{4}\right)^{2+} \cdot \mathrm{Cl}^{-}\right]^{+}=$ 1400.9271 Da.

7l-(BF4)2: $7 \mathrm{l}_{2} \quad$ (3.5 mg, $0.0024 \mathrm{mmol}, 1.0$ equiv.) was dissolved in DMF (1 mL), and separately $\mathrm{AgBF}_{4}(0.94 \mathrm{mg}$, $0.0048 \mathrm{mmol}, 2.0$ equiv.) was dissolved in DMF (1 mL). The two solutions were mixed and stirred under $\mathrm{N}_{2}$ in the dark for 2 hours. The resulting suspension was filtered through a celite plug, with the celite washed with more DMF $(2 \mathrm{~mL})$. The resulting yellow filtrate was taken to dryness under reduced pressure to given an orange-brown solid. Acetone $(5 \mathrm{~mL})$ was added and the suspension filtered to remove an insoluble brown solid. The filtrate was taken to dryness to give $7 \mathrm{l} \cdot\left(\mathrm{BF}_{4}\right)_{2}$ as a yellow powder. Yield: $2.0 \mathrm{mg}(0.0013 \mathrm{mmol}, 54 \%)$.
${ }^{1} \mathrm{H}$ NMR (d6-acetone): 10.05 (br. s, 2H), 9.92 (d, $J=1.2$ $\mathrm{Hz}, 4 \mathrm{H}), 8.72(\mathrm{~s}, 4 \mathrm{H}), 7.37-7.44(\mathrm{~m}, 2 \mathrm{OH}), 5.91$ (s, 8H) ppm. 19F NMR (d 6 -acetone): -152.53 (s), -152.47 (s) ppm. ESI-MS (pos.): 1453.1 , calc. for $\left[\left(\mathrm{C}_{52} \mathrm{H}_{38} \mathrm{~N}_{14} \mathrm{I}_{4}\right)^{2+\cdot}\left(\mathrm{BF}_{4}\right)^{-}\right]^{+}=1453.0 \mathrm{Da}$.

$8^{\mathrm{H} \cdot \mathrm{Cl}} 4$ : A mixture of $6 \mathrm{H} \cdot \mathrm{Cl}(0.339 \mathrm{~g}, 0.569 \mathrm{mmol}, 7.0$ equiv.) and tetra-amine 9 (0.031 g, $0.081 \mathrm{mmol}, 1.0$ equiv.) were dissolved in 1:1 ethanol:water $(40 \mathrm{~mL})$. The resulting orange solution was heated at $80^{\circ} \mathrm{C}$ for 7 days under $\mathrm{N}_{2}$. It was then cooled to room temperature and taken to dryness under reduced pressure to give an orange-red solid. This solid was suspended in acetonitrile $(10 \mathrm{~mL})$, sonicated, and then the resulting solid isolated by filtration to give the crude product as an orange powder. This powder was dissolved in methanol $(20 \mathrm{~mL})$ and then diethyl ether $(20 \mathrm{~mL})$ added resulting in the formation of a precipitate, which was isolated by filtration. This solid was suspended in acetone $(20 \mathrm{~mL})$ and sonicated, and the resulting pale brown powder isolated by filtration, washed with acetone $(3 \times 5 \mathrm{~mL})$ and diethyl ether $(5 \mathrm{~mL})$ to give $8^{\mathrm{H} \cdot \mathrm{Cl}}$. Yield: $0.053 \mathrm{~g}(0.026 \mathrm{mmol}, 32 \%)$.

${ }_{1} \mathrm{H}$ NMR ( $\left.\mathrm{d}_{6}-\mathrm{DMSO}\right): 9.59-9.66(\mathrm{~m}, 12 \mathrm{H}), 9.24(\mathrm{~s}, 8 \mathrm{H})$, 8.09-8.17 (m, 8H), $7.80(\mathrm{~d}, J=8.3 \mathrm{~Hz}, 8 \mathrm{H}), 7.34-7.44(\mathrm{~m}$, $40 \mathrm{H}), 5.80(\mathrm{~s}, 16 \mathrm{H}) \mathrm{ppm} .{ }^{13} \mathrm{C}$ NMR (d6-DMSO): 148.2 141.0, 140.7, 139.8, 135.7, 135.4, 131.5, 131.4, 128.9, 128.5, 128.2, 125.3, 125.2, 64.4, 53.5 ppm. HRESI-MS (pos.): 472.1992, calc. for $\left[\mathrm{C}_{117} \mathrm{H}_{92} \mathrm{~N}_{28}\right]^{4+}=472.2010 \mathrm{Da}$.

$8{ }^{\mathrm{H}} \cdot\left(\mathrm{PF}_{6}\right)_{4}: 8^{\mathrm{H} \cdot \mathrm{Cl}_{4}}(0.043 \mathrm{~g}, 0.021 \mathrm{mmol}, 1.0$ equiv. $)$ was dissolved in methanol $(5 \mathrm{~mL})$ with heating, and $\mathrm{NH}_{4} \mathrm{PF}_{6}$ ( $0.041 \mathrm{~g}, 0.25 \mathrm{mmol}, 12$ equiv.) in water $(2 \mathrm{~mL}$ ) was added resulting in the formation of a yellow precipitate. The mixture was left to stand for 2 hours and then the precipitate was isolated by filtration, washed with methanol $(3 \times 5 \mathrm{~mL})$ and diethyl ether $(5 \mathrm{~mL})$ and dried in vacuo to give $8^{\mathrm{H}} \cdot\left(\mathrm{PF}_{6}\right)_{4}$. Yield: $0.036 \mathrm{~g}$ (0.015 mmol, 70\%).

1H NMR (d 6 -DMSO): 9.52-9.58 (m, 12H), $9.10(\mathrm{~s}, 8 \mathrm{H})$, $8.08(\mathrm{~d}, J=8.4 \mathrm{~Hz}, 8 \mathrm{H}), 7.82(\mathrm{~d}, J=8.4 \mathrm{~Hz}, 8 \mathrm{H}), 7.35-7.44$ $(\mathrm{m}, 4 \mathrm{OH}), 5.80(\mathrm{~s}, 16 \mathrm{H})$ ppm. ${ }^{19} \mathrm{~F}$ NMR (d6-DMSO): -70.2 (d, J $=711 \mathrm{~Hz}$ ) ppm. ${ }^{31 \mathrm{P}}$ NMR (d6-DMSO): -144.2 (hept., $J=711$ $\mathrm{Hz}$ ppm. ESI-MS (pos.): 2323.9, calc. for $\left[\left(\mathrm{C}_{117} \mathrm{H}_{92} \mathrm{~N}_{28}\right)^{4+} \cdot\left(\mathrm{PF}_{6}\right)_{3}{ }^{3-}\right]^{+}=2323.9 \mathrm{Da} ; 1089.4$, calc. for $\left[\left(\mathrm{C}_{117} \mathrm{H}_{92} \mathrm{~N}_{28}\right)^{4+}\left(\mathrm{PF}_{6}\right)_{2}{ }^{2-}\right]^{2+}=1089.4 \mathrm{Da} ; 677.9$, calc. for $\left[\left(\mathrm{C}_{117} \mathrm{H}_{92} \mathrm{~N}_{28}\right)^{4+} \cdot\left(\mathrm{PF}_{6}\right)^{-}\right]^{3+}=678.0 \mathrm{Da}$.

\section{Acknowledgements}

We thank the Australian Research Council for financial support (AGRTP to EMF, FT210100495 to NGW).

\section{Notes and references}

1. Lin, R.-B.; He, Y.; Li, P.; Wang, H.; Zhou, W.; Chen, B., Multifunctional porous hydrogen-bonded organic framework materials. Chem. Soc. Rev. 2019, 48, 1362-1389.

2. Hisaki, I.; Xin, C.; Takahashi, K.; Nakamura, T., Designing HydrogenBonded Organic Frameworks (HOFs) with Permanent Porosity. Angew. Chem., Int. Ed. 2019, 58, 11160-11170. 
3. Hoskins, B. F.; Robson, R., Infinite polymeric frameworks consisting of three dimensionally linked rod-like segments. J. Am. Chem. Soc. 1989, $111,5962-4$

4. Li, H.; Eddaoudi, M.; O'Keeffe, M.; Yaghi, O. M., Design and synthesis of an exceptionally stable and highly porous metal-organic framework. Nature 1999, 402, 276

5. Côté, A. P.; Benin, A. I.; Ockwig, N. W.; O'Keeffe, M.; Matzger, A. J.; Yaghi, O. M., Porous, Crystalline, Covalent Organic Frameworks. Science 2005, 310, 1166-1170.

6. El-Kaderi, H. M.; Hunt, J. R.; Mendoza-Cortés, J. L.; Côté, A. P.; Taylor, R. E.; O'Keeffe, M.; Yaghi, O. M., Designed Synthesis of 3D Covalent Organic Frameworks. Science 2007, 316, 268-272.

7. Ermer, O., Five-fold diamond structure of adamantane-1,3,5,7tetracarboxylic acid. J. Am. Chem. Soc. 1988, 110, 3747-3754.

8. Simard, M.; Su, D.; Wuest, J. D., Use of hydrogen bonds to contro molecular aggregation. Self-assembly of three-dimensional networks with large chambers. J. Am. Chem. Soc. 1991, 113, 4696-4698.

9. Wuest, J. D., Engineering crystals by the strategy of molecular tectonics. Chem. Commun. 2005, 5830-5837.

10. He, Y.; Xiang, S.; Chen, B., A Microporous Hydrogen-Bonded Organic Framework for Highly Selective $\mathrm{C} 2 \mathrm{H} 2 / \mathrm{C} 2 \mathrm{H} 4$ Separation at Ambient Temperature. J. Am. Chem. Soc. 2011, 133, 14570-14573.

11. Mastalerz, M.; Oppel, I. M., Rational Construction of an Extrinsic Porous Molecular Crystal with an Extraordinary High Specific Surface Area. Angew. Chem., Int. Ed. 2012, 51, 5252-5255.

12. Chen, T.-H.; Popov, I.; Kaveevivitchai, W.; Chuang, Y.-C.; Chen, Y.-S. Daugulis, O.; Jacobson, A. J.; Miljanić, O. Š., Thermally robust and porous noncovalent organic framework with high affinity for fluorocarbons and CFCs. Nat. Commun. 2014, 5, 5131.

13. Hisaki, I.; Nakagawa, S.; Ikenaka, N.; Imamura, Y.; Katouda, M.; Tashiro, M.; Tsuchida, H.; Ogoshi, T.; Sato, H.; Tohnai, N.; Miyata, M., A Series of Layered Assemblies of Hydrogen-Bonded, Hexagonal Networks of C3-Symmetric п-Conjugated Molecules: A Potential Motif of Porous Organic Materials. J. Am. Chem. Soc. 2016, 138, 6617-6628.

14. Li, P.; Ryder, M. R.; Stoddart, J. F., Hydrogen-Bonded Organic Frameworks: A Rising Class of Porous Molecular Materials. Acc. Mater Res. 2020, 1, 77-87.

15. Russell, V. A.; Evans, C. C.; Li, W.; Ward, M. D., Nanoporous Molecular Sandwiches: Pillared Two-Dimensional Hydrogen-Bonded Networks with Adjustable Porosity. Science 1997, 276, 575-579.

16. Wahl, H.; Haynes, D. A.; le Roex, T., Porous salts based on the pamoate ion. Chem. Commun. 2012, 48, 1775-1777.

17. Roques, N.; Mouchaham, G.; Duhayon, C.; Brandès, S.; Tachon, A. Weber, G.; Bellat, J. P.; Sutter, J.-P., A Robust Nanoporous Supramolecular Metal-Organic Framework Based on Ionic Hydrogen Bonds. Chem. Eur. J. 2014, 20, 11690-11694.

18. Mottillo, C.; Friscic, T., Supramolecular imidazolium frameworks: direc analogues of metal azolate frameworks with charge-inverted node-andlinker structure. Chem. Commun. 2015, 51, 8924-8927.

19. Adachi, T.; Ward, M. D., Versatile and Resilient Hydrogen-Bonded Host Frameworks. Acc. Chem. Res. 2016, 49, 2669-2679.

20. Morshedi, M.; Thomas, M.; Tarzia, A.; Doonan, C. J.; White, N. G., Supramolecular anion recognition in water: synthesis of hydrogen-bonded supramolecular frameworks. Chem. Sci. 2017, 8, 3019-3025.

21. Xing, G.; Yan, T.; Das, S.; Ben, T.; Qiu, S., Synthesis of Crystalline Porous Organic Salts with High Proton Conductivity. Angew. Chem., Int. Ed. 2018, 57, 5345-5349.

22. Xing, G.; Bassanetti, I.; Bracco, S.; Negroni, M.; Bezuidenhout, C.; Ben, T.; Sozzani, P.; Comotti, A., A double helix of opposite charges to form channels with unique CO2 selectivity and dynamics. Chem. Sci. 2019, 10, 730-736.

23. White, N. G., Amidinium ‥carboxylate frameworks: predictable, robust, water-stable hydrogen bonded materials. Chem. Commun. 2021, 57 10998-11008.

24. Gilday, L. C.; Robinson, S. W.; Barendt, T. A.; Langton, M. J.; Mullaney, B. R.; Beer, P. D., Halogen Bonding in Supramolecular Chemistry. Chem. Rev. 2015, 115, 7118-7195.
25. Cavallo, G.; Metrangolo, P.; Milani, R.; Pilati, T.; Priimagi, A.; Resnati, G.; Terraneo, G., The Halogen Bond. Chem. Rev. 2016, 116, 2478-2601. 26. Lim, J. Y. C.; Beer, P. D., Sigma-Hole Interactions in Anion Recognition. Chem 2018, 4, 731-783.

27. Scilabra, P.; Terraneo, G.; Resnati, G., The Chalcogen Bond in Crystalline Solids: A World Parallel to Halogen Bond. Acc. Chem. Res. 2019, 52, 1313-1324.

28. Vogel, L.; Wonner, P.; Huber, S. M., Chalcogen Bonding: An Overview. Angew. Chem., Int. Ed. 2019, 58, 1880-1891.

29. Lindeman, S. V.; Hecht, J.; Kochi, J. K., The Charge-Transfer Motif in Crystal Engineering. Self-Assembly of Acentric (Diamondoid) Networks from Halide Salts and Carbon Tetrabromide as Electron-Donor/Acceptor Synthons. J. Am. Chem. Soc. 2003, 125, 11597-11606.

30. Rosokha, S. V.; Lu, J.; Rosokha, T. Y.; Kochi, J. K., Halogen-bonded assembly of hybrid inorganic/organic 3D-networks from dibromocuprate salts and tetrabromomethane. Chem. Commun. 2007, 3383-3385.

31. Metrangolo, P.; Meyer, F.; Pilati, T.; Proserpio, D. M.; Resnati, G., Highly Interpenetrated Supramolecular Networks Supported by $\mathrm{N} \cdots$ I Halogen Bonding. Chem. Eur. J. 2007, 13, 5765-5772.

32. Metrangolo, P.; Meyer, F.; Pilati, T.; Resnati, G.; Terraneo, G., Mutual induced coordination in halogen-bonded anionic assemblies with $(6,3)$ cation-templated topologies. Chem. Commun. 2008, 1635-1637.

33. Lieffrig, J.; Jeannin, O.; Fourmigué, M., Expanded Halogen-Bonded Anion Organic Networks with Star-Shaped lodoethynyl-Substituted Molecules: From Corrugated 2D Hexagonal Lattices to Pyrite-Type 2-Fold Interpenetrated Cubic Lattices. J. Am. Chem. Soc. 2013, 135, 6200-6210. 34. Szell, P. M. J.; Gabidullin, B.; Bryce, D. L., 1,3,5-Tri(iodoethynyl)-2,4,6trifluorobenzene: halogen-bonded frameworks and NMR spectroscopic analysis. Acta Crystallogr. Section B 2017, 73, 153-162.

35. Gunawardana, C. A.; Đaković, M.; Aakeröy, C. B., Diamondoid architectures from halogen-bonded halides. Chem. Commun. 2018, 54, 607-610.

36. Pfrunder, M. C.; Brock, A. J.; Brown, J. J.; Grosjean, A.; Ward, J.; McMurtrie, J. C.; Clegg, J. K., A three-dimensional cubic halogen-bonded network. Chem. Commun. 2018, 54, 3974-3976.

37. Nikolayenko, V. I.; Castell, D. C.; van Heerden, D. P.; Barbour, L. J., Guest-Induced Structural Transformations in a Porous Halogen-Bonded Framework. Angew. Chem., Int. Ed. 2018, 57, 12086-12091.

38. Gong, G.; Lv, S.; Han, J.; Xie, F.; Li, Q.; Xia, N.; Zeng, W.; Chen, Y.; Wang, L.; Wang, J.; Chen, S., Halogen-Bonded Organic Framework (XOF) Based on lodonium-Bridged $\mathrm{N} \cdots \mathrm{I}+\cdots \mathrm{N}$ Interactions: A Type of Diphase Periodic Organic Network. Angew. Chem., Int. Ed. 2021, 60, 14831-14835. 39. Werz, D. B.; Staeb, T. H.; Benisch, C.; Rausch, B. J.; Rominger, F.; Gleiter, R., Self-Organization of Chalcogen-Containing Cyclic Alkynes and Alkenes To Yield Columnar Structures. Org. Lett. 2002, 4, 339-342.

40. Gleiter, R.; Werz, D. B.; Rausch, B. J., A World Beyond Hydrogen Bonds?-Chalcogen-Chalcogen Interactions Yielding Tubular Structures. Chem. Eur. J. 2003, 9, 2676-2683.

41. Mehrparvar, S.; Wölper, C.; Gleiter, R.; Haberhauer, G., The Carbonyl...Tellurazole Chalcogen Bond as a Molecular Recognition Unit: From Model Studies to Supramolecular Organic Frameworks. Angew. Chem., Int. Ed. 2020, 59, 17154-17161.

42. Yang, W.; Jiang, R.; Liu, C.; Yu, B.; Cai, X.; Wang, H., Triptycene-Based Porous Chalcogen-Bonded Organic Frameworks. Cryst. Growth Des. 2021, 21, 6497-6503.

43. Eckstein, B. J.; Brown, L. C.; Noll, B. C.; Moghadasnia, M. P.; Balaich, G. J.; McGuirk, C. M., A Porous Chalcogen-Bonded Organic Framework. J. Am. Chem. Soc. 2021, 143, 20207-20215.

44. Li, Y.-j.; Zhao, Y.-j.; Flood, A. H.; Liu, C.; Liu, H.-b.; Li, Y.-I., NanometerSized Reactor-A Porphyrin-Based Model System for Anion Species. Chem. Eur. J. 2011, 17, 7499-7505.

45. White, N. G.; Beer, P. D., A catenane host system containing integrated triazole $\mathrm{C}-\mathrm{H}$ hydrogen bond donors for anion recognition. Chem. Commun. 2012, 48, 8499-8501.

46. Langton, M. J.; Robinson, S. W.; Marques, I.; Felix, V.; Beer, P. D. Halogen bonding in water results in enhanced anion recognition in acyclic and rotaxane hosts. Nat. Chem. 2014, 6, 1039-1043. 
47. Lim, J. Y. C.; Liew, J. Y.; Beer, P. D., Thermodynamics of Anion Binding by Chalcogen Bonding Receptors. Chem. Eur. J. 2018, 24, 14560-14566. 48. Robinson, S. W.; Mustoe, C. L.; White, N. G.; Brown, A.; Thompson, A L.; Kennepohl, P.; Beer, P. D., Evidence For Halogen Bond Covalency In Acyclic and Interlocked Halogen-Bonding Receptor Anion Recognition. J. Am. Chem. Soc. 2015, 137, 499-507.

49. Shang, J.; Zhao, W.; Li, X.; Wang, Y.; Jiang, H., Aryl-triazole foldamers incorporating a pyridinium motif for halide anion binding in aqueous media. Chem. Commun. 2016, 52, 4505-4508.

50. Lim, J. Y. C.; Marques, I.; Félix, V.; Beer, P. D., Enantioselective Anion Recognition by Chiral Halogen-Bonding [2]Rotaxanes. J. Am. Chem. Soc 2017, 139, 12228-12239.

51. Bunchuay, T.; Docker, A.; Martinez-Martinez, A. J.; Beer, P. D., A Potent Halogen-Bonding Donor Motif for Anion Recognition and Anion Template Mechanical Bond Synthesis. Angew. Chem., Int. Ed. 2019, 58, 13823 13827.

52. Dreger, A.; Engelage, E.; Mallick, B.; Beer, P. D.; Huber, S. M., The role of charge in 1,2,3-triazol(ium)-based halogen bonding activators. Chem Commun. 2018, 54, 4013-4016.

53. A similar arrangment around sulfate was previously observed by Schubert: Schulze, B.; Friebe, C.; Hager, M. D.; Günther, W.; Köhn, U.; Jahn B. O.; Görls, H.; Schubert, U. S.; Anion Complexation by Triazolium "Ligands:: Mono- and Bis-tridentate Complexes of Sulfate, Org. Lett. 2010, 12, 2710-2713.

54. Bosch, E.; Barnes, C. L., Synthesis and Crystallographic Characterization of a Novel Platinocycle. Organometallics 2000, 19, 55225524.

55. J. Bjerrum, G. Schwarzenbach, L. Gunnar Sillen, Stability constants of metal-ion complexes, Chemical Society, London, 1958.

56. Alvarez, S., A cartography of the van der Waals territories. Dalton Trans. 2013, 42, 8617-8636.

57. Spek, A. L., PLATON SQUEEZE: a tool for the calculation of the disordered solvent contribution to the calculated structure factors. Acta Crystallogr. Section C, 2015, 71, 9-18.

58. Walter, S. M.; Kniep, F.; Herdtweck, E.; Huber, S. M., Halogen-Bond Induced Activation of a Carbon-Heteroatom Bond. Angew. Chem., Int. Ed. 2011, 50, 7187-7191.

59. Castelli, R.; Schindler, S.; Walter, S. M.; Kniep, F.; Overkleeft, H. S.; Van der Marel, G. A.; Huber, S. M.; Codée, J. D. C., Activation of Glycosyl Halides by Halogen Bonding. Chem. Asian. J. 2014, 9, 2095-2098.

60. Bulfield, D.; Huber, S. M., Halogen Bonding in Organic Synthesis and Organocatalysis. Chem. Eur. J. 2016, 22, 14434-14450.

61. Taylor, R.; Wood, P. A., A Million Crystal Structures: The Whole Is Greater than the Sum of Its Parts. Chem. Rev. 2019.

62. Cheng, W.-C.; Kurth, M. J., The Zincke Reaction. A Review. Org. Prep. Proced. Int. 2002, 34, 585-608.

63. Lee, S.; Hua, Y.; Park, H.; Flood, A. H., Intramolecular Hydrogen Bonds Preorganize an Aryl-triazole Receptor into a Crescent for Chloride Binding. Org. Lett. 2010, 12, 2100-2102.

64. Lankshear, M. D.; Beer, P. D., Interweaving Anion Templation. Acc. Chem. Res. 2007, 40, 657-668.

65. Cowieson, N. P.; Aragao, D.; Clift, M.; Ericsson, D. J.; Gee, C. H., Stephen J.; Mudie, N.; Panjikar, S.; Price, J. R.; Riboldi-Tunnicliffe, A.; Williamson, R.; Caradoc-Davies, T., MX1: a bending-magnet crystallography beamline serving both chemical and macromolecular crystallography communities at the Australian Synchrotron. J. Synchrotron Radiat. 2015, 22, 187--190.

66. Aragao, D.; Aishima, J.; Cherukuvada, H.; Clarken, R.; Clift, M.; Cowieson, N. P.; Ericsson, D. J.; Gee, C. L.; Macedo, S.; Mudie, N.; Panjikar, S.; Price, J. R.; Riboldi-Tunnicliffe, A.; Rostan, R.; Williamson, R.; Caradoc-Davies, T. T., MX2: a high-flux undulator microfocus beamline serving both the chemical and macromolecular crystallography communities at the Australian Synchrotron. J. Synchrotron Radiat. 2018, 25, 885-891.

67. CrysAlis PRO, Oxford Diffraction: 2011.

68. Kabsch, W., XDS. Acta Crystallogr. Section D, 2010, 66, 125-132.
69. Palatinus, L.; Chapuis, G., SUPERFLIP. A computer program for the solution of crystal structures by charge flipping in arbitrary dimensions. $J$. Appl. Crystallogr. 2007, 40, 786-790.

70. Sheldrick, G., SHELXT - Integrated space-group and crystal-structure determination. Acta Crystallogr. Section A, 2015, 71, 3-8.

71. Betteridge, P. W.; Carruthers, J. R.; Cooper, R. I.; Prout, K.; Watkin, D. J., CRYSTALS version 12: software for guided crystal structure analysis. J. Appl. Crystallogr. 2003, 36, 1487.

72. Dolomanov, O. V.; Bourhis, L. J.; Gildea, R. J.; Howard, J. A. K.; Puschmann, H., OLEX2: a complete structure solution, refinement and analysis program. J. Appl. Crystallogr. 2009, 42, 339-341.

73. Alvarez, S. G.; Alvarez, M. T., A Practical Procedure for the Synthesis of Alkyl Azides at Ambient Temperature in Dimethyl Sulfoxide in High Purity and Yield. Synthesis 1997, 1997, 413-414.

74. Zhang, M.; Chen, Y.-P.; Zhou, H.-C., Structural design of porous coordination networks from tetrahedral building units. CrystEngComm 2013, 15, 9544-9552.

75. Plietzsch, O.; Schilling, C. I.; Tolev, M.; Nieger, M.; Richert, C.; Muller, T.; Bräse, S., Four-fold click reactions: Generation of tetrahedral methaneand adamantane-based building blocks for higher-order molecular assemblies. Org. Biomol. Chem. 2009, 7, 4734-4743.

76. Lowe, A. J.; Pfeffer, F. M., Size matters-strong binding of the terephthalate dianion by thiourea functionalised fused [n]polynorbornane hosts. Chem. Commun. 2008, 1871-1873.

77. Boer, S. A.; Morshedi, M.; Tarzia, A.; Doonan, C. J.; White, N. G., Molecular Tectonics: A Node-and-Linker Building Block Approach to a Family of Hydrogen-Bonded Frameworks. Chem. Eur. J. 2019, 25, 1000610012

78. Drefahl, G.; Lorenz, D., Polymerisationsfähige und polymere Verbindungen. III. Notiz zur Darstellung des Tetra-p-vinylphenyl-silans. J. Prakt. Chem. 1964, 24, 312-314. 